Article

\title{
Inorganic Element Determination of Romanian Populus nigra L. Buds Extract and In Vitro Antiproliferative and Pro-Apoptotic Evaluation on A549 Human Lung Cancer Cell Line
}

\author{
Brigitta Kis ${ }^{1}{ }^{(0}$, Ioana Zinuca Pavel ${ }^{1,2}, * \mathbb{D}$, Daniela Haidu ${ }^{3}$, Mariana Nela Ștefănuț ${ }^{4}$, Zorița Diaconeasa ${ }^{5} \mathbb{D}^{(}$, \\ Elena-Alina Moacă ${ }^{2,6} \oplus$, Cristina Adriana Dehelean ${ }^{2,6}$, Simona Șipos ${ }^{7}$, Alexandra Ivan ${ }^{8}$ and Corina Danciu ${ }^{1,2}$
}

check for updates

Citation: Kis, B.; Pavel, I.Z.; Haidu, D.; Ștefănut, M.N.; Diaconeasa, Z.; Moacă, E.-A.; Dehelean, C.A.; Șipos, S.; Ivan, A.; Danciu, C. Inorganic Element Determination of Romanian Populus nigra L. Buds Extract and In Vitro Antiproliferative and Pro-Apoptotic Evaluation on A549 Human Lung Cancer Cell Line. Pharmaceutics 2021, 13, 986. https:// doi.org/10.3390/pharmaceutics 13070986

Academic Editors: Javier Garcia-Pardo, Maria Camilla Bergonzi, Charles M. Heard and Bruno Sarmento

Received: 12 May 2021

Accepted: 24 June 2021

Published: 29 June 2021

Publisher's Note: MDPI stays neutral with regard to jurisdictional claims in published maps and institutional affiliations.

Copyright: (C) 2021 by the authors. Licensee MDPI, Basel, Switzerland. This article is an open access article distributed under the terms and conditions of the Creative Commons Attribution (CC BY) license (https:// creativecommons.org/licenses/by/ $4.0 /)$
1 Department of Pharmacognosy, "Victor Babeș” University of Medicine and Pharmacy Timișoara, 300041 Timișoara, Romania; kis.brigitta@umft.ro (B.K.); corina.danciu@umft.ro (C.D.)

2 Research Centre for Pharmaco-Toxicological Evaluation, "Victor Babes" University of Medicine and Pharmacy, 300041 Timisoara, Romania; alina.moaca@umft.ro (E.-A.M.); cadehelean@umft.ro (C.A.D.)

3 Romanian Academy “Coriolan Dragulescu” Institute of Chemistry, 300223 Timisoara, Romania; danielahaidul@gmail.com

4 Laboratory of Electrochemical and Chemical Technologies, Department of Chemical and Electrochemical Syntheses, National Institute of Research and Development for Electrochemistry and Condensed Matter, 300569 Timişoara, Romania; mariana.stefanut@gmail.com

5 Department of Food Science and Technology, Faculty of Food Science and Technology, University of Agricultural Science and Veterinary Medicine, 400372 Cluj-Napoca, Romania; zorita.diaconeasa@gmail.com

6 Department of Toxicology, "Victor Babes" University of Medicine and Pharmacy Timișoara, 300041 Timisoara, Romania

7 Department of Biochemistry and Pharmacology, Faculty of Medicine, "Victor Babeș" University of Medicine and Pharmacy, 300041 Timisoara, Romania; sipos.simona@umft.ro

8 Department of Immunology, Faculty of Medicine, "Victor Babeș" University of Medicine and Pharmacy Timișoara, 300041 Timișoara, Romania; ivan.alexandra@umft.ro

* Correspondence: ioanaz.pavel@umft.ro; Tel.: +40-256-494-604

\begin{abstract}
Populus nigra L. is a plant from Salicaceae family, native in Europe. Many parts of this tree can be used as active ingredients, but the most valuable are the buds. In recent years, a growing number of studies reported their activity in the development of a wide range of pharmacological activities including diabetes, cardiovascular diseases, and cancer. The aim of this study was to determine the phytochemical composition and to evaluate the inorganic elements' concentration as well as the in vitro antiproliferative and pro-apoptotic potential of a Populus nigra L. buds extract collected from Timișoara (Romania) against A549 human lung cancer cell line. Populus nigra L. bud extract was found to contain twelve different phenolic compounds. The inorganic elements concentrations were below the limit of detection for $\mathrm{Co}, \mathrm{Pb}$, and As, whereas $\mathrm{Cu}=6.66 \mu \mathrm{g} / \mathrm{g} ; \mathrm{Cr}=0.79 \mu \mathrm{g} / \mathrm{g}$; $\mathrm{Ni}=3.28 \mu \mathrm{g} / \mathrm{g}$; $\mathrm{Fe}=39.00 \mu \mathrm{g} / \mathrm{g} ; \mathrm{Zn}=14.84 \mu \mathrm{g} / \mathrm{g} ; \mathrm{Mn}=0.59 \mu \mathrm{g} / \mathrm{g} ; \mathrm{Al}=2109.87 \mu \mathrm{g} / \mathrm{g} ;$ and $\mathrm{Cd}=0.019 \mu \mathrm{g} / \mathrm{g}$. The extract was tested for the in vitro antiproliferative and pro-apoptotic potential on A549 human lung cancer cell line using different concentrations, namely 10, 25, 50, 75, 100, and $150 \mu \mathrm{g} / \mathrm{mL}$. Results have shown that poplar bud extract induced a significant decrease of tumor cell viability in a dosedependent manner with an $\mathrm{IC}_{50}=72.49 \mu \mathrm{g} / \mathrm{mL}$ and blocked the cells in the G0/G1 phase of the cell cycle. Phenomena of early apoptosis (from $1.34 \pm 0.33 \%$ control cells to $2.68 \pm 0.62 \%$ at $150 \mu \mathrm{g} / \mathrm{mL}$ ) and late apoptosis (from $1.43 \pm 0.14 \%$ control cells to $5.15 \pm 1.02 \%$ at $150 \mu \mathrm{g} / \mathrm{mL}$ ) were detected by Annexin V-PI double staining. Poplar bud extract can be regarded as a promising candidate for future studies involving lung cancer.
\end{abstract}

Keywords: Populus nigra L. extract; phenolic compounds; inorganic elements; A549 lung cancer cell migration; apoptosis; cytotoxicity 


\section{Introduction}

The long historical use of plants per se or as different types of extracts for their medicinal benefits is well documented in comprehensive reviews on this topic [1-3]. To date, there have been a growing number of studies concerning the potential benefits of plant extracts for a wide range of pathologies. Among the most reported biological activities assigned to various plant extracts can be listed the anti-inflammatory, antimicrobial, antidiabetic, cardioprotective, neuroprotective, hepatoprotective, vasorelaxant, hypouricemic, and anti-tumoral properties $[4,5]$.

Populus nigra L., commonly known as black poplar, is a well-known medicinal plant, belonging to the Salicaceae family. Black poplar is an indigenous tree widespread in almost all continents. In Romania. it grows along rivers, through streams and meadows, and in the regions of hills and plains. In terms of lifespan, black poplar enjoys a true longevity, commonly 300-400 years [6]. Black poplar can be easily confused with white poplar (Populus alba L.) and aspen (Populus tremula L.). To the extent that during the harvesting period the leaves have not yet appeared, the differentiation will be made after the bark and buds aspect. In the case of the black poplar, the bark forms an early furrowed rhytidome on most of the stem. For the other species, the rhytidome appears only in old trees, the young ones showing a smooth white-gray or gray-green bark. The buds of black poplar are 2-3 cm long and 5-8 $\mathrm{mm}$ thick, elongated, and sharp, with a length of $2-3 \mathrm{~cm}$. Due to the resins that cover the surface, they present a shiny appearance and an aromatic smell. For the other species, the buds are ovoid and smaller. The period of harvest is before the development of the leaves, especially from February to April, when the vegetative buds start to swell [7-9].

In recent years, a series of studies have been conducted in order to characterize the phytochemical composition of black poplar buds. It has been also underlined the fact that black poplar buds have a number of chemical similarities to propolis (a resinous product collected by bees) [10,11]. Studies on the resin obtained from poplar buds harvested from Populus nigra L. have shown the presence of various flavonic derivatives, flavonols, and also flavanones $[12,13]$. The range of phenolic derivatives identified is also quite wide. Thus, the presence of caffeic, dimethylcaffeic, and isoferulic acids, as well as their esters, was also established. Esters of isoferulic acid with aliphatic and aromatic alcohols are present in significant amounts and appear to predominate in the extract. Among the terpene components identified in poplar buds extract, the most important is bisabolol. In black poplar bark extracts, salicylic acid glycosides, salicortin, salireposide, benzoic acid derivatives, populin (salicin-6-benzoate), and tremulacin (salicin-2-benzoate) were also identified. Additionally, phytochemical investigations have revealed the presence of tannins, triterpene derivatives, wax, $\alpha$ - and $\beta$-amirenol, glucose, and fructose $[14,15]$.

Poplar tree species have been extensively studied in different countries because of their beneficial effects on human health. However, the interest in this species has grown mainly in the Western area [16]. Many parts of this tree, such as the buds, leaves, and bark, can be used as active ingredients for the pharmaceutical industry. In European traditional medicine, black poplar buds were generally recommended as a remedy in respiratory infections (cough, laryngitis, bronchitis, sore throat) and also in the treatment of dermatological problems (psoriasis), rheumatic inflammations, and hemorrhoids [17].

In recent years, a growing number of evidence-based studies regarding black poplar bud pharmacological activity have been published. With respect to this direction, this vegetal product was reported to have strong antioxidant activity with a potential similar to the activity of ascorbic acids [18]. The antioxidant activity may be assigned to the high content of phenolic compounds, especially caffeic and isoferulic acids [19,20]. Medicinal plants rich in polyphenols represent a high antioxidant activity due to their hydrogendonating and metal chelating capacities [21]. It is well known that oxidative stress plays an important role in the development of many diseases including cardiovascular diseases, diabetes, and various types of cancer [22]. 
Today, a wide range of plant extracts are commonly used. From the point of view of the quality and contained elements, it is also important to verify the content of toxic elements such as $\mathrm{As}, \mathrm{Cd}, \mathrm{Pb}$, and $\mathrm{Hg}$ [23]. The formulation of a phytopharmaceutical product includes several important aspects such as the medicinal plant from which the active principles come (evaluation of the content of toxic elements, especially in the case of plants that are used for phytoremediation) and evaluation of the finished product to define active principles, ensuring that it is not contaminated with toxic metals either from the handling process or from the extractive process [24,25]. The organic composition of black poplar bud extracts has been the focus of some studies, regarding the characterization and quantification of the active compounds present, together with their effects on human health [26-28]. In contrast, there are few studies on the characterization of inorganic components of extracts and their potential effects on human health [29]. Recent studies assumed the accumulation of heavy metals in different parts of the plant, such as in roots, where they found more $\mathrm{Cd}, \mathrm{Cu}$, and $\mathrm{Pb}$ contents than in the leaves or stems. Using black poplar buds as a vegetal product for obtaining a therapeutic extract, we can assume that the risk of contamination is minimal. Populus nigra L. presents significant defense mechanisms against $\mathrm{Cd}, \mathrm{Cu}$, and $\mathrm{Pb}$ with values up to $7.8,29.8$, and $91.1 \mathrm{mg} / \mathrm{kg}$ soil. On the other hand, the tolerance index (TI) of either biomass or root was $>0.8$. Many deciduous plant species are believed to translocate accumulated heavy metals to their above-ground tissues before senescence [30]. However, the quantity of heavy metals that accumulates in the aerial part of the Populus nigra L. extract showed appreciable potential for storing heavy metals like $\mathrm{Cd}$ and $\mathrm{Zn}$ in aging foliage [31,32].

The aim of the study was to conduct a phytochemical characterization of Populus nigra L. buds extract (noted further Pg) obtained from the western areas of Romania and to determine the inorganic elements as well as the in vitro evaluation on the A549 human lung cancer cell line in terms of viability, migration, apoptosis, and cytotoxicity.

\section{Materials and Methods}

\subsection{Plant Materials and Reagents}

Pg was collected from Timișoara (Romania) and identified in the Department of Pharmacognosy, University of Medicine and Pharmacy "Victor Babes" (specimen number is Pg 3/2019). The extraction was performed as previously described [33]. Briefly, for the extraction, $10 \mathrm{~g}$ of dried Pg was measured and was mixed with $100 \mathrm{~mL}$ ethanol $70 \%$. The extract was ultrasonicated in the FALC LBS 2 ultrasonic water bath for $30 \mathrm{~min}$ and then filtered with filter paper using a vacuum pump (Vacuubrand). The solvent was evaporated using a rotary evaporator (HEIDOLPH Laborata 4000 efficient WB eco). To earn a dry sample, the Pg extract was placed in an oven for $5-6 \mathrm{~h}$ at $50{ }^{\circ} \mathrm{C}$ (Genlab N40c).

\subsection{Phytochemical Composition-HPLC-DAD}

ESI-MS (electrospray ionization coupled with mass spectrometry) analysis was performed on an Agilent 1200 system (Chelmsford, MA, USA) that was equipped with a binary pump delivery system LC-20 AT (Prominence), a degasser DGU-20 A3 (Prominence), and a diode array SPD-M20 UV-VIS detector (DAD). The separation of the compounds was achieved on an Eclipse XDB C18 column $(4 \mu \mathrm{m}, 4.6 \times 150 \mathrm{~mm})$. The mobile phases consisted of solvent A, bidistilled water and $0.1 \%$ acetic acid/acetonitrile (99/1) $v / v$, while solvent B was acetonitrile and acetic acid $0.1 \%$. The gradient elution system was programmed as follows: 0-2 min, isocratic with 5\% $(v / v)$ eluent $\mathrm{B} ; 2-18 \mathrm{~min}$, linear gradient from $5 \%$ to $40 \%(v / v)$ eluent $B ; 18-20 \mathrm{~min}$, linear gradient from $40 \%$ to $90 \%(v / v)$ eluent B; 20-24 min, isocratic on $90 \%(v / v)$ eluent B; $24-25 \mathrm{~min}$, linear gradient from $90 \%$ to $5 \%$ $(v / v)$ eluent $B ; 25-30 \mathrm{~min}$, isocratic on $5 \%(v / v)$ eluent $B$. Flow rate was set to $0.5 \mathrm{~mL} / \mathrm{min}$, and column temperature was maintained at $25{ }^{\circ} \mathrm{C}$. The chromatograms were monitored at 280 and $340 \mathrm{~nm}$. Identification of the compounds and peak assignments were done using their retention time, UV-VIS, and mass spectra, and also when comparing with the commercial standards (chlorogenic acid, caffeic acid, apigenin) and previously published 
literature. A single quadrupole 6110 mass spectrometer (Agilent Technologies, Chelmsford, MA, USA) equipped with an ESI probe was used for the mass spectrometric measurements. Measurements were performed in the positive mode with an ion spray voltage of $3000 \mathrm{~V}$ and a capillary temperature of $350^{\circ} \mathrm{C}$. Data were collected in full scan mode within the range of 100 to $1200 \mathrm{~m} / z$. For the quantification, the standard curve of chlorogenic acid was used and expressed as a $\mathrm{mg} / \mathrm{g}$ sample.

\subsection{Inorganic Element Determination of Pg Extracts by GF-AAS-Sampling and Sample Preparation}

Prior to the analyses, all the glassware and plastic vessels were washed properly and rinsed with ultrapure water. About $0.1 \mathrm{~g}$ of plant extract was treated with $5.0 \mathrm{~mL} 67 \%$ nitric acid (Sigma Aldrich, Jena, Germany) and subjected to microwave acidic digestion (Table 1). Each determination was performed in triplicate. Metal concentrations were determined using a spectrophotometer novAA 400G (Analytik Jena, Jena, Germany) equipped with a graphite furnace, an auto sampler MPE60, and a Cookbook for all elements. The analyses and data were processed with a WinAAS 3.17.0 soft.

Table 1. Program parameters ( $\mathrm{T}$-temperature, $\mathrm{t}$-time, $\mathrm{P}$ - power) from the acidic digestion with microwave system MWS-2, realized in three steps.

\begin{tabular}{|c|c|c|c|c|c|c|c|c|c|}
\hline & $T_{1}$ & $t_{1}$ & $\mathbf{P}_{1}$ & $T_{2}$ & $t_{2}$ & $\mathbf{P}_{2}$ & $T_{3}$ & $t_{3}$ & $\mathbf{P}_{3}$ \\
\hline $\begin{array}{c}\text { Program } \\
\text { Parameters }\end{array}$ & $160^{\circ} \mathrm{C}$ & $15 \mathrm{~min}$ & $80 \%$ & $210^{\circ} \mathrm{C}$ & $15 \mathrm{~min}$ & $90 \%$ & $\begin{array}{l}\text { gradual } \\
\text { decrease in } \\
\text { temperature }\end{array}$ & $15 \mathrm{~min}$ & 0 \\
\hline
\end{tabular}

For each element, a calibration curve with standard Merck solutions was previously registered (Table 2). All solutions were prepared with ultrapure water (Barnstead, EASYpure $\mathrm{RoDi}^{\circledR}$ apparatus).

Table 2. Characteristics for standard calibration curves.

\begin{tabular}{ccccccc}
\hline No. & Metal & $\begin{array}{c}\text { Wavelength, } \boldsymbol{\lambda} \\
(\mathbf{n m})\end{array}$ & $\begin{array}{c}\text { Lower Limit, } \\
(\boldsymbol{\mu} \mathbf{g} / \mathbf{L})\end{array}$ & $\begin{array}{c}\text { Upper Limit, } \\
(\boldsymbol{\mu} \mathbf{g} / \mathbf{L})\end{array}$ & Calibration Curve & $\mathbf{R}^{\mathbf{2}}$ \\
\hline 1 & $\mathrm{Cu}$ & 324.8 & 3.6 & 18 & $\mathrm{y}=0.020731+0.016628 \mathrm{x}$ & 0.9961 \\
2 & $\mathrm{~Pb}$ & 283.3 & 7.4 & 37 & $\mathrm{y}=0.001778+0.003524 \mathrm{x}$ & 0.9994 \\
3 & $\mathrm{As}$ & 193.7 & 13.2 & 58.1 & $\mathrm{y}=0.00185+0.001544 \mathrm{x}$ & 0.9927 \\
4 & $\mathrm{Zn}$ & 213.9 & 1 & 8 & $\mathrm{y}=0.071658+0.092202 \mathrm{x}$ & 0.9827 \\
5 & $\mathrm{Mn}$ & 297.5 & 0.84 & 4.2 & $\mathrm{y}=0.007792+0.112496 \mathrm{x}$ & 0.9925 \\
6 & $\mathrm{Ni}$ & 232.0 & 4.2 & 34.6 & $\mathrm{y}=0.033774+0.011603 \mathrm{x}$ & 0.9967 \\
7 & $\mathrm{Cd}$ & 228.8 & 0.1 & 2.2 & $\mathrm{y}=0.004734+0.071971 \mathrm{x}$ & 0.9923 \\
8 & $\mathrm{Cr}$ & 357.9 & 5 & 22.0 & $\mathrm{y}=0.018371+0.018435 \mathrm{x}$ & 0.9961 \\
9 & $\mathrm{Co}$ & 240.7 & 5.4 & 29.4 & $\mathrm{y}=0.008353+0.010864 \mathrm{x}$ & 0.9929 \\
10 & $\mathrm{Al}$ & 309.3 & 13.2 & 58.2 & $\mathrm{y}=0.006978+0.00175 \mathrm{x}$ & 0.9971 \\
11 & $\mathrm{Fe}$ & 248.3 & 3.6 & 14.4 & $\mathrm{y}=0.02274+0.013974 \mathrm{x}$ & 0.9939 \\
\hline
\end{tabular}

\subsection{Cell Culture}

A549 lung adenocarcinoma cell line (ATCC ${ }^{\circledR}$ CCL-185 ${ }^{\mathrm{TM}}$ ) was purchased from the American Type Culture Collection (ATCC ${ }^{\circledR}$ PCS-301-010 ${ }^{\mathrm{TM}}$ ). The cells were cultured in Dulbecco's Modified Eagle's Medium (DMEM; Sigma-Aldrich, (Taufkirchen, Germany) and supplemented with 10\% fetal bovine serum (FBS; Sigma-Aldrich, Taufkirchen, Germany) and 1\% penicillin/streptomycin mixture (Pen/Strep, 10,000 IU/mL; Sigma-Aldrich, Taufkirchen, Germany) and further maintained in standard conditions (humidified atmosphere with $5 \% \mathrm{CO}_{2}$ and $37^{\circ} \mathrm{C}$ ). 


\subsection{MTT Assay}

The antiproliferative activity of Pg against A549 cells was assessed using the MTT (3-(4,5-dimethylthiazol-2-yl)-2,5-diphenyltetrazolium bromide) assay. The experiments were effectuated as previously described by Ghitu et al. [34]. Briefly, cells were seeded at a density of $1 \times 10^{4}$ cells/well in 96-well culture plates and allowed to adhere overnight at $37^{\circ} \mathrm{C}$. After $24 \mathrm{~h}$ of incubation, A549 cells were stimulated with diverse concentrations of $\operatorname{Pg}(10,25,50,75,100$, and $150 \mu \mathrm{g} / \mathrm{mL})$ and incubated for $72 \mathrm{~h}$. Dimethyl sulfoxide (DMSO), the solvent used to make the stock solution, was used as a control in this experiment. At $72 \mathrm{~h}$ post-stimulation, the cells were treated with $10 \mu \mathrm{L}$ of $5 \mathrm{mg} / \mathrm{mL}$ MTT solution (Sigma-Aldrich) and incubated for another additional $3 \mathrm{~h}$. The formazan crystals were dissolved in $100 \mu \mathrm{L}$ of lysis solution, and the absorbance was determined at $570 \mathrm{~nm}$ using the microplate reader (BioRad, xMark Microplate Spectrophotometer).

\subsection{Scratch Assay}

To evaluate the regressive effect of Pg on the invasion capacity of A549 lung adenocarcinoma cells, the scratch test was performed [35]. A number of $2 \times 10^{5}$ cells/well were seeded onto 12 -well culture plates. When $90 \%$ confluence was reached, the attached cells were scratched following the diameter of the well using a sterile pipette tip. Afterward, the wells were washed with phosphate-buffered saline PBS (Thermo Fisher Scientific, Boston, MA, USA), and the cells were stimulated with different concentrations of $\operatorname{Pg}(10,25,50,75$, 100 , and $150 \mu \mathrm{g} / \mathrm{mL}$ ). In order to compare the cell growth of the stimulated vs. control cells in early stages, the wells were captured on images at 0 and $24 \mathrm{~h}$ using the Olympus IX73 inverted microscope provided with DP74 camera (Olympus, Tokyo, Japan). The cellSense Dimension software was used for analyzing the cell migration. The scratch closure rate was calculated using the following formula [34]:

$$
\text { Scratch closure rate }=\left[\frac{A_{t_{0}}-A_{t}}{A_{t_{0}}}\right] * 100
$$

where $A_{t 0}$ is the scratch area at time $0 ; A_{t}$ is the scratch area at $24 \mathrm{~h}$.

\subsection{Cell Cycle Analysis}

In order to distinguish the cell cycle distribution, the cell's DNA content analysis was determined by FACSCalibur flow cytometer (Becton-Dickinson, Franklin Lakes, NJ, USA). A549 human lung cancer cells were seeded into 6-well plates and were treated with Pg extracts using the different concentrations mentioned above. After $48 \mathrm{~h}$, following trypsinization and centrifugation, cells were collected and fixed with ice-cold $70 \%$ ethanol $(1000 \mu \mathrm{L})$ and stored for $30 \mathrm{~min}$ at $5{ }^{\circ} \mathrm{C}$. Prior to analysis, the cells were centrifuged for $5 \mathrm{~min}$ at $1500 \mathrm{rpm}$ and re-suspended in PBS. Thereupon, $50 \mu \mathrm{L}$ of PI (BD Pharmingen, BD Biosciences) was added to the cells and then incubated for $10 \mathrm{~min}$ at $4{ }^{\circ} \mathrm{C}$. As a control, cells treated with $0.15 \%$ DMSO were used. Using the Flowing software 2.5.1., the percentage of cells present in the different cell cycle (G0, G1, S, and G2) phases was determined [36].

\subsection{Detection of Apoptosis via 4',6-Diamidino-2-Phenylindole (DAPI) Staining}

The apoptotic potential of Pg at the selected concentrations was analyzed by DAPI staining. A549 lung adenocarcinoma cells were plated onto $6=$ well plates $\left(5 \times 10^{5}\right.$ cells $/$ well $)$ and left to adhere overnight. The next day, the medium was removed and a fresh one containing Pg in different concentrations $(10,25,50,75,100$, and $150 \mu \mathrm{g} / \mathrm{mL})$ was added. After $72 \mathrm{~h}$, the cells were washed twice with ice-cold PBS and then were fixed with $4 \%$ paraformaldehyde in PBS, permeabilized with $2 \%$ Triton- X/PBS for $30 \mathrm{~min}$, and blocked with $30 \%$ FCS $/ 0.01 \%$ Triton-X. After, as a final step, the cells were washed again with PBS and stained with DAPI ( $300 \mathrm{nM})$ in a dark chamber for $15 \mathrm{~min}$. In order to take fluorescent images at a magnification of 40X, we use the fluorescence inverted microscope Olympus IX73, which had an integrated DP74 digital camera (Olympus, Tokyo, Japan) [37]. 


\subsection{Annexin V-FITC Apoptosis Assay}

Pg extract was examined by flow cytometric analysis with the Annexin V-FITC apoptosis detection kit (Sigma-Aldrich) according to the manufacturer's protocol. A 6-well plate was used and cells were seeded at the concentrations of $10^{4}$ cells/well and incubate overnight. The next day, the media were removed and a fresh medium containing the Pg extracts $(10,25,50,75,100$, and $150 \mu \mathrm{g} / \mathrm{mL})$ was added. After $72 \mathrm{~h}$, the cells were trypsinized, washed twice with BB (Binding Buffer), centrifuged at $1500 \mathrm{rpm}$ for $7 \mathrm{~min}$, and resuspended in BB and then incubated with $5 \mu \mathrm{L}$ of Annexin V-FITC for $15 \mathrm{~min}$ at room temperature. After the washing steps, the pellet was resuspended in a $190 \mu \mathrm{L} \mathrm{BB}$, and immediately $10 \mu \mathrm{L}$ PI (propidium iodide) solution was added prior to analysis by flow cytometry. The solvent DMSO $(0.15 \%)$ was used as the control. A549 cells were examined by flow cytometry (FACSCalibur, Becton Dickinson) using the fluorescence channel FL1 for Annexin and FL2 for PI, and results were interpreted using Flowing Software 2.5.1. [38].

\subsection{LDH Assay}

The LDH (lactate dehydrogenase) assay (11644793001 Roche) was performed to determine the cytotoxic effect of Pg using different concentrations (10, 25, 50, 75, 100, and $150 \mu \mathrm{g} / \mathrm{mL}$ ). The experiment was performed according to the manufacturer's protocol. For this experiment, a number of $5 \times 10^{3}$ cells/well were seeded in 96-well culture plates and left to adhere overnight. On the next day, the cells were stimulated with the abovementioned concentrations of Pg and incubated for $72 \mathrm{~h}$. The next step consists of transferring $100 \mu \mathrm{L}$ from each well into a new 96-well culture plate, mixing with $100 \mu \mathrm{L} /$ well of the reaction mixture, and further incubating for $30 \mathrm{~min}$ at room temperature. Using a microplate reader (BioRad, xMark Microplate Spectrophotometer), the level of LDH release in the medium was measured at 490 and $680 \mathrm{~nm}$. To establish spontaneous and maximum release of LDH, cells treated with 1\% $(v / v)$ Triton X-100 (high control) and untreated cells (low control) were used [34].

\subsection{Statistical Analysis}

The data obtained in the present study are expressed as mean \pm standard deviation. A one-way ANOVA test followed by Dunnett's multiple comparison test was used for comparison among groups. GraphPad Prism 5 (GraphPad Software, San Diego, CA, USA) was used for the statistical analysis.

\section{Results}

\subsection{Phytochemical Composition}

The extract showed a high content in phenolic compounds. Liquid chromatography (LC) separations of the phenolic compound are presented in Figure 1 and their identification in Table 3. The Pg extract was found to contain twelve different phenolic compounds consisting of dihydroxybenzoic acid, protocatechuic acid, 3-caffeoylquinic acid, 5-caffeoylquinic acid, caffeic acid, chicoric acid, apigenin-glucuronide, chrysoeriolglucuronide, tremuloidin, salicin, pinostrobin, and tremulacin. The identification was further confirmed by comparison of their chromatographic retention times and mass spectrometry (MS) fragmentation spectra with those of standards and data available in the literature $[39,40]$. Prior to LC separation, Peak $1(\mathrm{Rt}=2.96)$ with an $[\mathrm{M}-\mathrm{H}]^{+}$ion peak at $m / z 155$ in the ESI mass spectrum was confirmed as a dihydroxybenzoic acid. Further, the mass spectral value of compound 2 showed a quasi-molecular ion $[\mathrm{M}-\mathrm{H}]^{-}$ at $m / z 155$ with a UV max at $280 \mathrm{~nm}$ that was identified as a protocatechuic acid. The electrospray ionization coupled with mass spectrometry (ESI-MS) of compounds 3 and 4 showed a quasi-molecular ion $[\mathrm{M}-\mathrm{H}]^{-}$at $m / z$ 355; both are the same mass value, only the position is different; those compounds were identified based on available standards as 3-caffeoylquinic acid (neochlorogenic acid) and 5-caffeoylquinic acid (chlorogenic acid), respectively. 


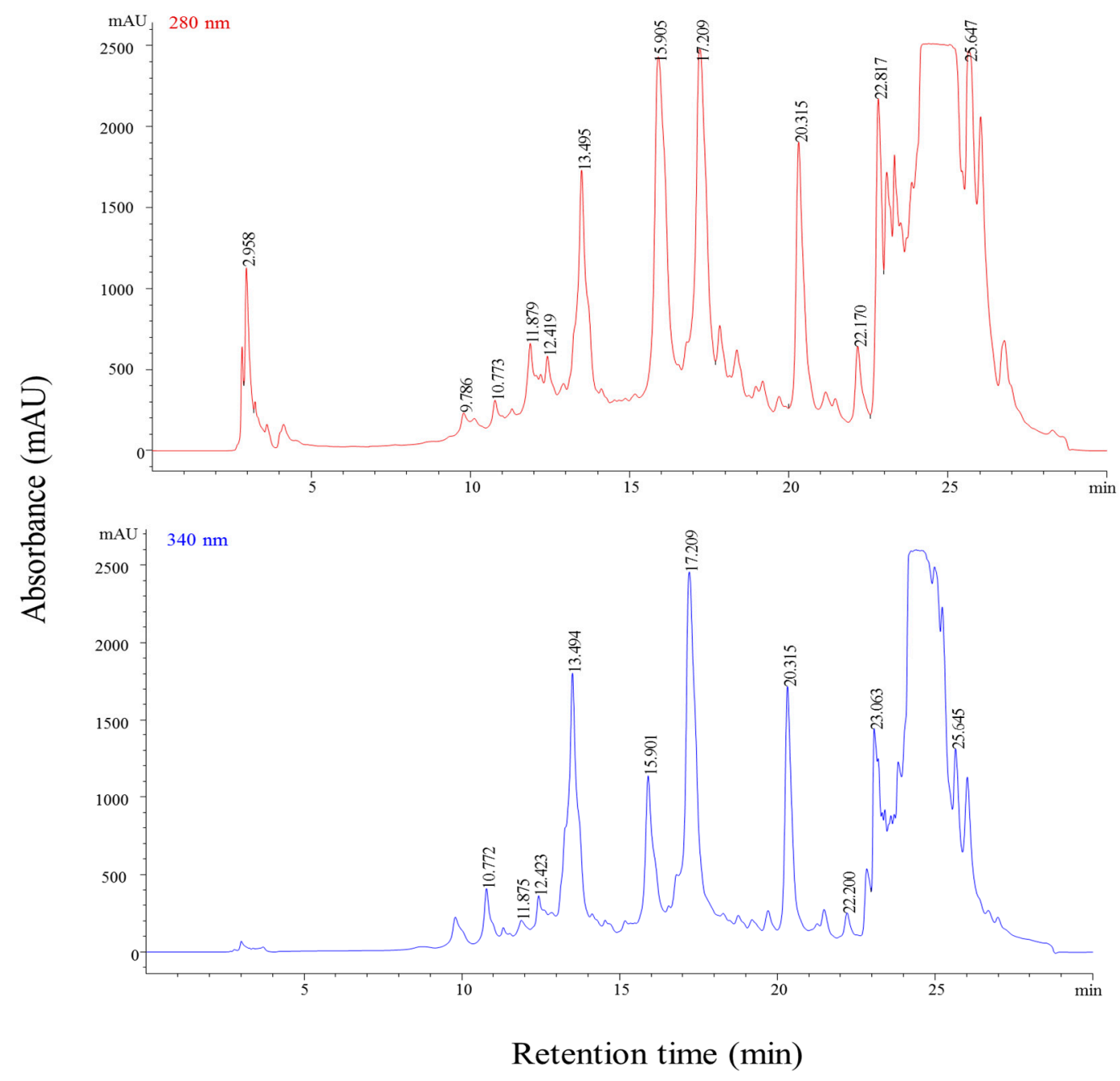

Figure 1. LC chromatogram of Pg extract (20 mg at 280 and $340 \mathrm{~nm}$ ).

Table 3. Phenolic compounds in poplar bud samples obtained by LC-MS analysis.

\begin{tabular}{|c|c|c|c|c|c|}
\hline Peak No. & $\begin{array}{c}\text { Retention Time } \mathbf{R}_{\mathrm{t}} \\
(\mathrm{min})\end{array}$ & {$[\mathbf{M}+\mathrm{H}]^{+}(m / z)$} & $\mathrm{UV} \lambda_{\max }(\mathrm{nm})$ & Compound & Subclass \\
\hline 1 & 2.96 & 155 & 278 & Dihydroxybenzoic acid & Hydroxybenzoic acid \\
\hline 2 & 9.78 & 155 & 280 & Protocatechuic acid & Hydroxybenzoic acid \\
\hline 3 & 10.28 & 355,163 & 322 & $\begin{array}{l}\text { 3-Caffeoylquinic acid } \\
\text { (Neochlorogenic acid) }\end{array}$ & Hydroxycinnamic acid \\
\hline 4 & 11.89 & 355,163 & 322 & $\begin{array}{l}\text { 5-Caffeoylquinic acid } \\
\text { (Chlorogenic acid) }\end{array}$ & Hydroxycinnamic acid \\
\hline 5 & 12.52 & 181,163 & 320 & Caffeic acid & Hydroxycinnamic acid \\
\hline 6 & 13.52 & 475,181 & 320 & Chicoric acid & Hydroxycinnamic acid \\
\hline 7 & 15.90 & 447,271 & 312,240 & Apigenin-glucuronide & Flavone \\
\hline 8 & 17.21 & 477 & 310,240 & $\begin{array}{l}\text { Chrysoeriol } \\
\text {-glucuronide }\end{array}$ & Flavone \\
\hline 9 & 20.31 & 389 & 320,230 & Tremuloidin & Salicin benzoate ester \\
\hline 10 & 22.17 & 287 & 278 & Salicin & Hydroxybenzoic acid \\
\hline 11 & 22.81 & 271 & 312,290 & Pinostrobin & Flavanone \\
\hline 12 & 25.64 & 529 & 290,230 & Tremulacin & Salicin ester \\
\hline
\end{tabular}

Next, two more hydroxycinnamic acids were identified (compounds 5 and 6 ) corresponding to caffeic and chicoric acid, confirmed with MS via the ion $m / z$, while the next three peaks $(7,8$, and 9$)$ were flavone derivatives that defined a fragment at $m / z 447,477$, 
and 285, respectively, corresponding to apigenin-glucuronide, chrysoeriol-glucuronide, and tremuloidin. Compound $\mathbf{1 0}$ was detected as salicin, while compound $\mathbf{1 1}$ was pinostrobin, which belongs to the flavanone class. The last compound with ultraviolet-visible (UV-VIS) data $(\lambda \max 312,240)$ showed an $[\mathrm{M}-\mathrm{H}]^{+}$ion at $\mathrm{m} / \mathrm{z} 271$; this was identified as tremulacin. Quantitative analysis revealed that the analysis sample was very high in flavone, as depicted in Table 4. Apigenin-glucuronide was demonstrated to be a major compound, found in an amount of $55.828 \mathrm{mg} / \mathrm{g}$ chlorogenic acid equivalent (CCE). Chryglucuronide and tremuloidin were also the most abundant compounds among all the phenolics identified.

Table 4. The number of phenolic compounds in the poplar bud sample, expressed in $\mathrm{mg} / \mathrm{g}$ chlorogenic acid equivalent (CCE).

\begin{tabular}{cccc}
\hline Peak No. & Rt (min) & Compound & Amount mg/g CEE \\
\hline 1 & 2.96 & Dihydroxybenzoic acid & 13.022 \\
2 & 9.78 & Protocatechuic acid & 2.674 \\
3 & 10.28 & 3-Caffeoylquinic acid & 3.382 \\
& & (Neochlorogenic acid) & \\
4 & 11.89 & 5-Caffeoylquinic acid & 8.216 \\
5 & 12.52 & (Chlorogenic acid) & 4.983 \\
6 & 13.52 & Caffeic acid & 30.021 \\
7 & 15.90 & Chicoric acid & 55.828 \\
8 & 17.21 & Apigenin-glucuronide & 48.765 \\
9 & 20.31 & Chry-glucuronide & 30.459 \\
10 & 22.17 & Tremuloidin & 8.874 \\
11 & 22.81 & Salicin & 18.307 \\
12 & 25.64 & Pinostrobin & 14.642 \\
\hline
\end{tabular}

\subsection{Inorganic Elements}

Results show that in the tested sample, the concentrations of the obtained elements vary from $0.019 \mu \mathrm{g} / \mathrm{g}$ for $\mathrm{Cd}$ to $2109.87 \mu \mathrm{g} / \mathrm{g}$ for $\mathrm{Al}$ (Table 5). The used measurement unit is $\mu \mathrm{g} / \mathrm{g}$ (which is the equivalent of ppm and $\mathrm{mg} / \mathrm{kg}$ ). Arsenic, lead, and cobalt were below the limit of detection.

Table 5. Final concentration of metals $(\mu \mathrm{g} / \mathrm{g})$, as mean of three determinations.

\begin{tabular}{cccccccccccc}
\hline Metal & Co & Cu & Cr & Ni & Fe & Zn & Pb & Mn & Al & As & Cd \\
\hline Media & ${ }^{*}$ udl & 6.66 & 0.79 & 3.28 & 39.00 & 14.84 & ${ }^{*}$ udl & 0.59 & 2109.87 & $*$ udl & 0.019 \\
SD & - & 0.10 & 0.01 & 0.01 & 0.05 & 0.06 & - & 0.01 & 14.02 & - & 0.001 \\
\hline
\end{tabular}

${ }^{*}$ udl-under the detection limit.

\subsection{MTT Assay}

The effect of Pg was evaluated on the A549 lung adenocarcinoma cell line following a stimulation period of $72 \mathrm{~h}$ with the selected concentrations. Results obtained on the tumor cell line are depicted in Figure 2. It can be observed that Pg provoked a dose-dependent decrease of tumor cells' viability, the highest decrease of viability being $53 \pm 3.1 \%$ (at $150 \mu \mathrm{g} / \mathrm{mL})$ vs. control. A significant decrease of tumor cell viability was also obtained at $25 \mu \mathrm{g} / \mathrm{mL}(93 \pm 2.9 \%), 50 \mu \mathrm{g} / \mathrm{mL}(88 \pm 6.7 \%), 75 \mu \mathrm{g} / \mathrm{mL}(72 \pm 3.8 \%)$, and $100 \mu \mathrm{g} / \mathrm{mL}$ (67.2 $\pm 4.5 \%$ ). The $\mathrm{IC}_{50}$ value calculated using GraphPad Prism was $72.49 \mu \mathrm{g} / \mathrm{mL}$ (Table 6). 


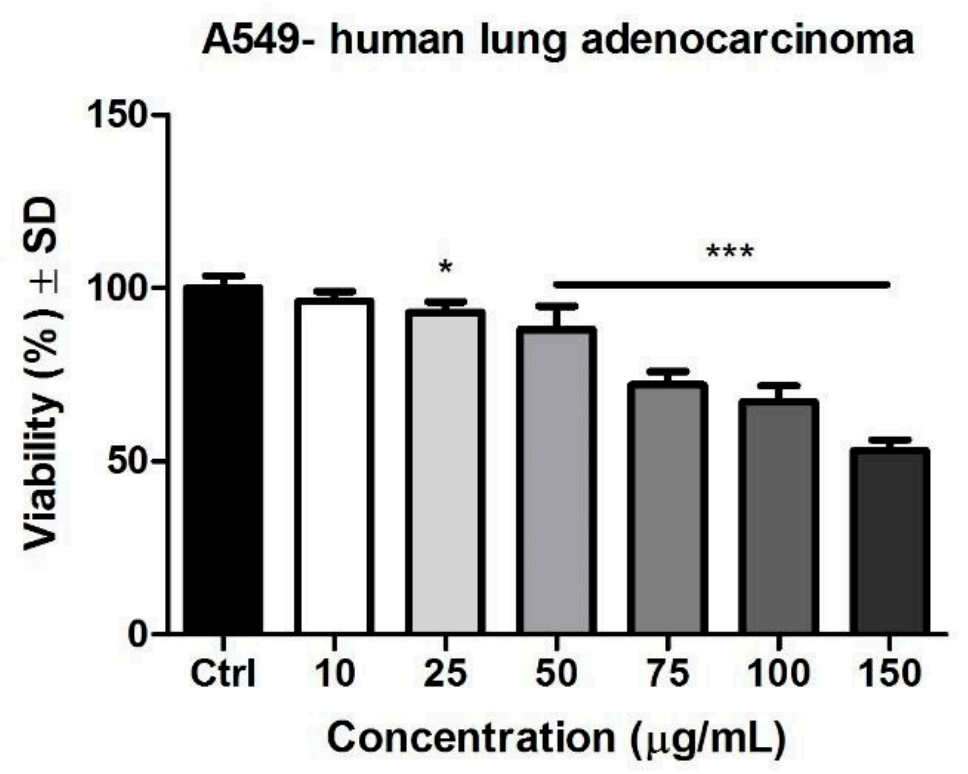

Figure 2. $\operatorname{Pg}(10,25,50,75,100$, and $150 \mu \mathrm{g} / \mathrm{mL})$ effect on A549 human lung adenocarcinoma cells viability after $72 \mathrm{~h}$ stimulation. The data are expressed as cell viability percentage (\%) related to the control cells. A one-way ANOVA test and Dunnett's multiple comparison post-test were employed for comparison among groups $\left({ }^{*} p<0.05,{ }^{* * *} p<0.001\right.$ vs. Control).

Table 6. $\mathrm{IC}_{50}$ values of Pg extract on A549 human lung adenocarcinoma cells at $72 \mathrm{~h}$ post-stimulation.

\begin{tabular}{cc}
\hline Extract & ${\text { A549 } \mathrm{IC}_{50}(\mu \mathrm{g} / \mathrm{mL})}^{7}$ \\
\hline Pg extract & 72.49 \\
\hline
\end{tabular}

\subsection{Scratch Assay}

The potential anti-migratory effect of Pg extract on A549 lung adenocarcinoma cells was determined by means of a scratch assay. Results have shown that this extract decreased tumor cell migration in a dose-dependent way, and at the highest dose tested $(150 \mu \mathrm{g} / \mathrm{mL})$, it produced changes in A549 cells' morphology (Figure 3).

Figure 4 represents the scratch closure rate for the selected concentrations. It can be noticed that Pg produced a decrease in the closure rate in a dose-dependent manner, indicating that the extract elicited an anti-migratory effect on A549 lung adenocarcinoma cells. At the highest doses, the scratch closure rate was $14.1 \%$ for $100 \mu \mathrm{g} / \mathrm{mL}$ and $12.5 \%$ for $150 \mu \mathrm{g} / \mathrm{mL}$.

\subsection{Cell Cycle Analysis}

In order to understand the effect of the ethanolic extract of Pg on the A549 cell cycle profile, the nuclear DNA content of the cells was analyzed by flow cytometry following $72 \mathrm{~h}$ treatment. DMSO was used as a solvent control for the assay, while untreated cells were used as a negative control. A tendency to block the A549 human lung cancer cells in the G0/G1 phase of the cell cycle could be observed (Figure 5). The percentage of cells in this phase was slightly increased from $73.42 \% \pm 2.44$ (control cells) to $78.80 \pm 0.52$ $(150 \mu \mathrm{g} / \mathrm{mL} \mathrm{Pg})$ after treatment with the Pg extract. Simultaneously, the percentage of cells in the mitosis phase $(\mathrm{G} 2 / \mathrm{M})$ decreased from $13.84 \% \pm 0.51$ in the control cells to $9.99 \% \pm 1.44$ for the cells treated with the highest tested concentration $(150 \mu \mathrm{g} / \mathrm{mL} \mathrm{Pg})$ of Pg. Figure 6 presents the histogram of cell cycle analysis. Results are presented as the mean of three independent experiments \pm standard deviation. 
Control

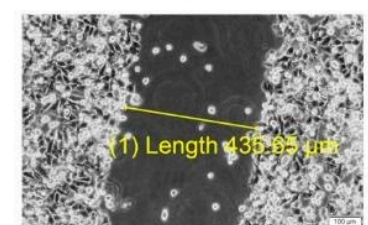

$4 \mathrm{~h}$

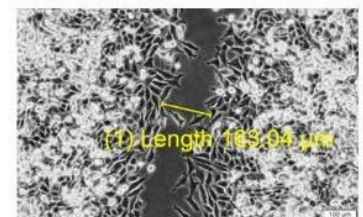

Control

Oh

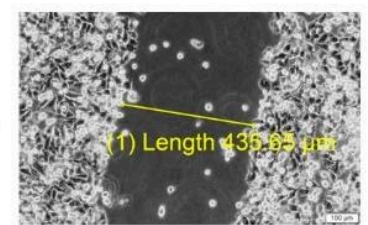

$4 \mathrm{~h}$

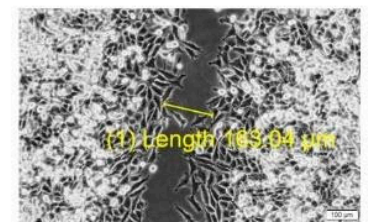

$\mathrm{Pg} 10 \mathrm{ug} / \mathrm{mL}$
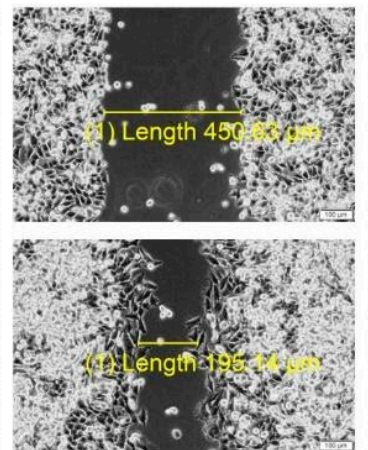

Pg 75 ug $/ \mathrm{mL}$
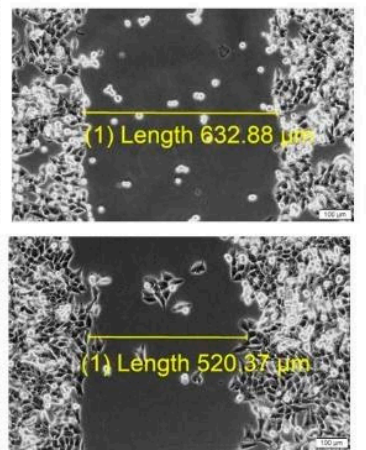

$\mathrm{Pg} 25 \mathrm{ug} / \mathrm{mL}$
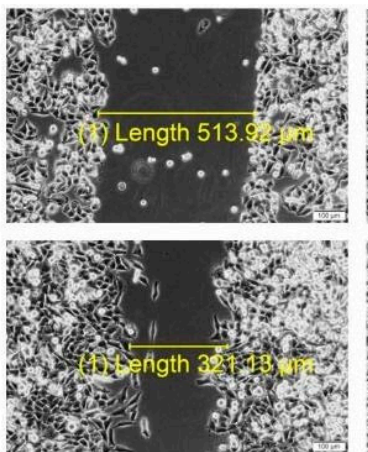

$\mathrm{Pg} 100 \mathrm{ug} / \mathrm{mL}$
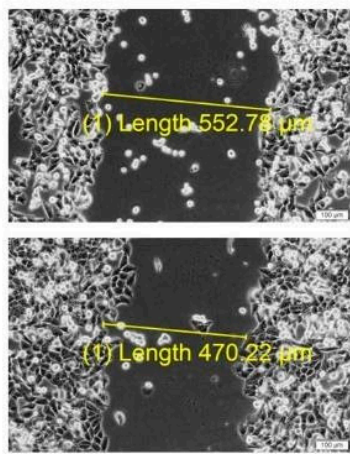

$\mathrm{Pg} 50 \mathrm{ug} / \mathrm{mL}$

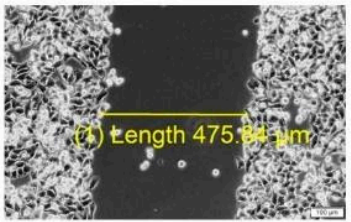

(a)

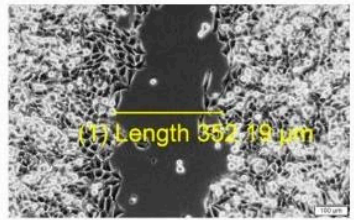

$\mathrm{Pg} 150$ ug/mL

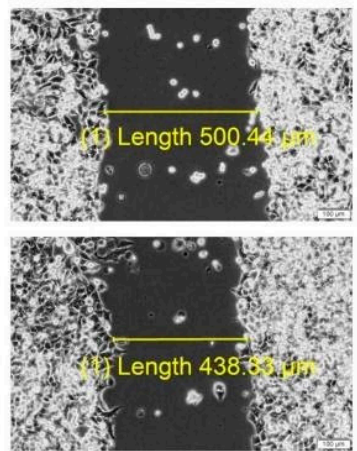

(b)

Figure 3. Pg extract (a) (10, 25 and 50) and (b) (75, 100, and $150 \mu \mathrm{g} / \mathrm{mL})$ activity on A549 human lung adenocarcinoma cells' migration and proliferation potential. Progression of cell migration was monitored by imaging the scratch line initially and at $24 \mathrm{~h}$ post-stimulation. Images were taken by light microscopy at $10 \times$ magnification.

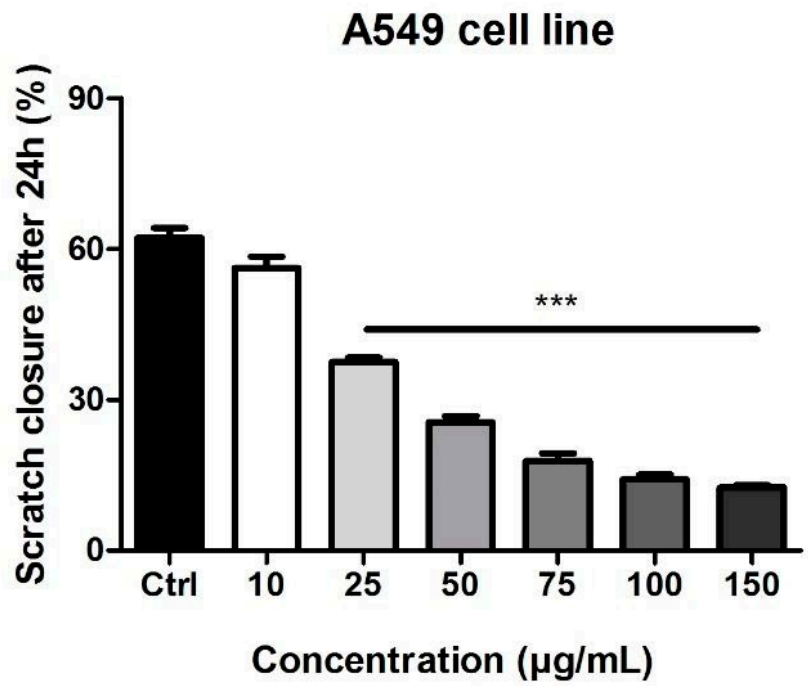

Figure 4. The anti-migratory potential of Pg extract (10, 25, 50, 75, 100, and $150 \mu \mathrm{g} / \mathrm{mL})$ on A549 lung adenocarcinoma cells. The bar graphs are expressed as percentage of scratch closure after $24 \mathrm{~h}$ compared to the initial surface. One-way ANOVA test and Dunnett's multiple comparison post-test were employed for comparison among groups (*** $p<0.001$ vs. Control). 


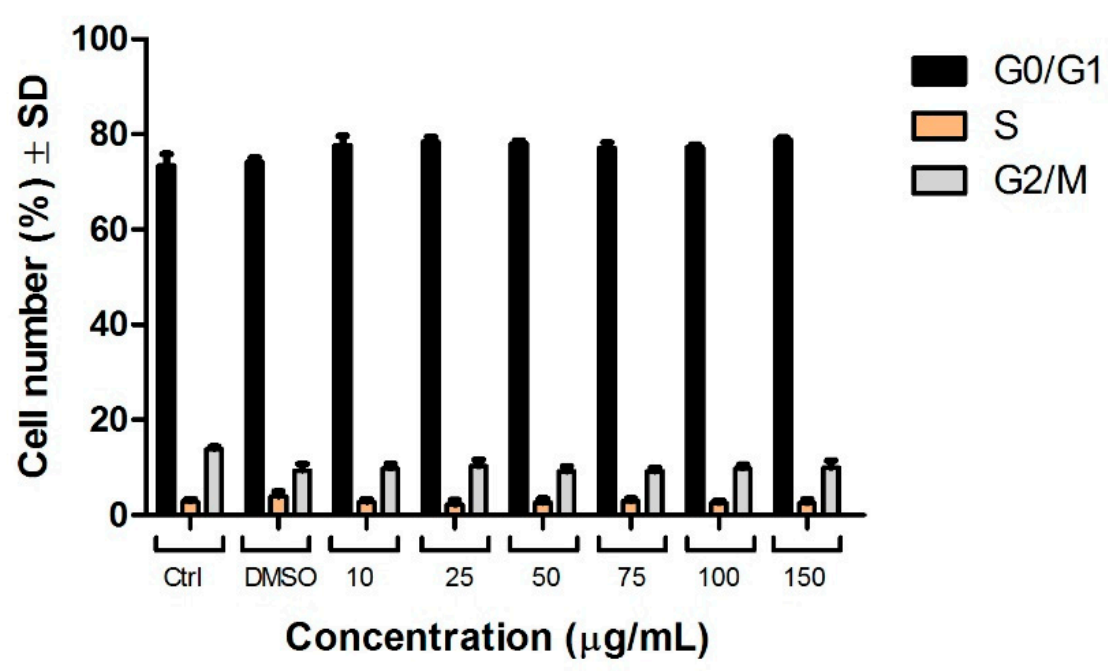

Figure 5. A549 human lung adenocarcinoma cell cycle analysis after stimulation with Pg extract (10, 25, 50, 75, 100, and $150 \mu \mathrm{g} / \mathrm{mL}$ ) on G0/G1; S and G2/M phases. The results are expressed as cell number percentage $(\%) \pm$ standard deviation.

\subsection{DAPI Staining}

The taken images (Figure 7) indicate that there is chromatin condensation following stimulation with Pg extract. The control showed a normal organization and a uniform chromatin density. Under the current experimental conditions, deoxyribonucleic acid (DNA) fragmentation was not observed. The data obtained show that after treatment with Pg extract, the A549 tumor cells manifested signs of apoptosis.

\subsection{Annexin PI}

In order to verify whether the Pg extract has an effect on early apoptosis, late apoptosis, or necrosis, the Annexin V-FITC/PI assay was performed using flow cytometry. Figure 8 presents the flow-cytometry dot-plots for the cells treated with different concentrations of $\operatorname{Pg}(10,25,50,75,100$, and $150 \mu \mathrm{g} / \mathrm{mL})$, control, and DMSO. A very slight effect of apoptosis induction was observed after cell exposure to the Pg extract; the percentage in early apoptotic cells after $72 \mathrm{~h}$ treatment with Pg extracts increased from $1.34 \pm 0.33 \%$ (untreated cells) to $2.68 \pm 0.62 \%$ (cells treated with the highest concentration). The percentage of early apoptosis cells after Pg extract treatment are control- $1.34 \pm 0.33 \%$, DMSO- $-1.77 \pm 0.15 \%, 10 \mu \mathrm{g} / \mathrm{mL}-1.70 \pm 0.47 \%, 25 \mu \mathrm{g} / \mathrm{mL}-1.27 \pm 0.12 \%, 50 \mu \mathrm{g} / \mathrm{mL}-$ $1.34 \pm 0.33 \%, 75 \mu \mathrm{g} / \mathrm{mL}-1.97 \pm 0.77 \%, \quad 100 \mu \mathrm{g} / \mathrm{mL}-1.47 \pm 0.42 \%$, and $150 \mu \mathrm{g} / \mathrm{mL}$ $-2.68 \pm 0.62 \%$. Regarding the percentage of late apoptotic cells, a slight increase from $1.43 \% \pm 0.14$ (control cells) to $5.15 \% \pm 1.02$ (the highest concentration of $150 \mu \mathrm{g} / \mathrm{mL}$ ) was observed, while the other concentrations tested did not produce a notable increase in late apoptotic cells' percentage. The percentage of late apoptosis cells are as follows: control$1.43 \pm 0.14 \%$, DMSO-1.32 $\pm 0.15 \%, 10 \mu \mathrm{g} / \mathrm{mL}-2.04 \pm 0.49 \%, 25 \mu \mathrm{g} / \mathrm{mL}-1.92 \pm 0.45 \%$, $50 \mu \mathrm{g} / \mathrm{mL}-1.92 \pm 0.30 \%, 75 \mu \mathrm{g} / \mathrm{mL}-1.47 \pm 0.08 \%, 100 \mu \mathrm{g} / \mathrm{mL}-2.10 \pm 0.24 \%$, and $150 \mu \mathrm{g} / \mathrm{mL}-5.15 \pm 1.02 \%(p<0.001)$ (Figure 9$)$. The percentage of viable cells decreased from $97.12 \pm 0.04 \%$ in the case of untreated cells (control) to $92.01 \pm 0.02 \%$ in the case of exposure to $150 \mu \mathrm{g} / \mathrm{mL}$ of Pg extract, while the percentage of necrotic cells was significantly increased after treatment with Pg extract at the concentrations of 50 and $75 \mu \mathrm{g} / \mathrm{mL}$ (control $-0.12 \pm 0.12 \%, 50 \mu \mathrm{g} / \mathrm{mL}-0.60 \pm 0.11 \%$, and $75 \mu \mathrm{g} / \mathrm{mL}-0.62 \pm 0.02 \%$,). Correlated to the above-mentioned determinations, the study proved that, statistically, Pg extract at the highest concentration tested $(150 \mu \mathrm{g} / \mathrm{mL})$ can induce phenomena of late apoptosis when compared to control cells. 

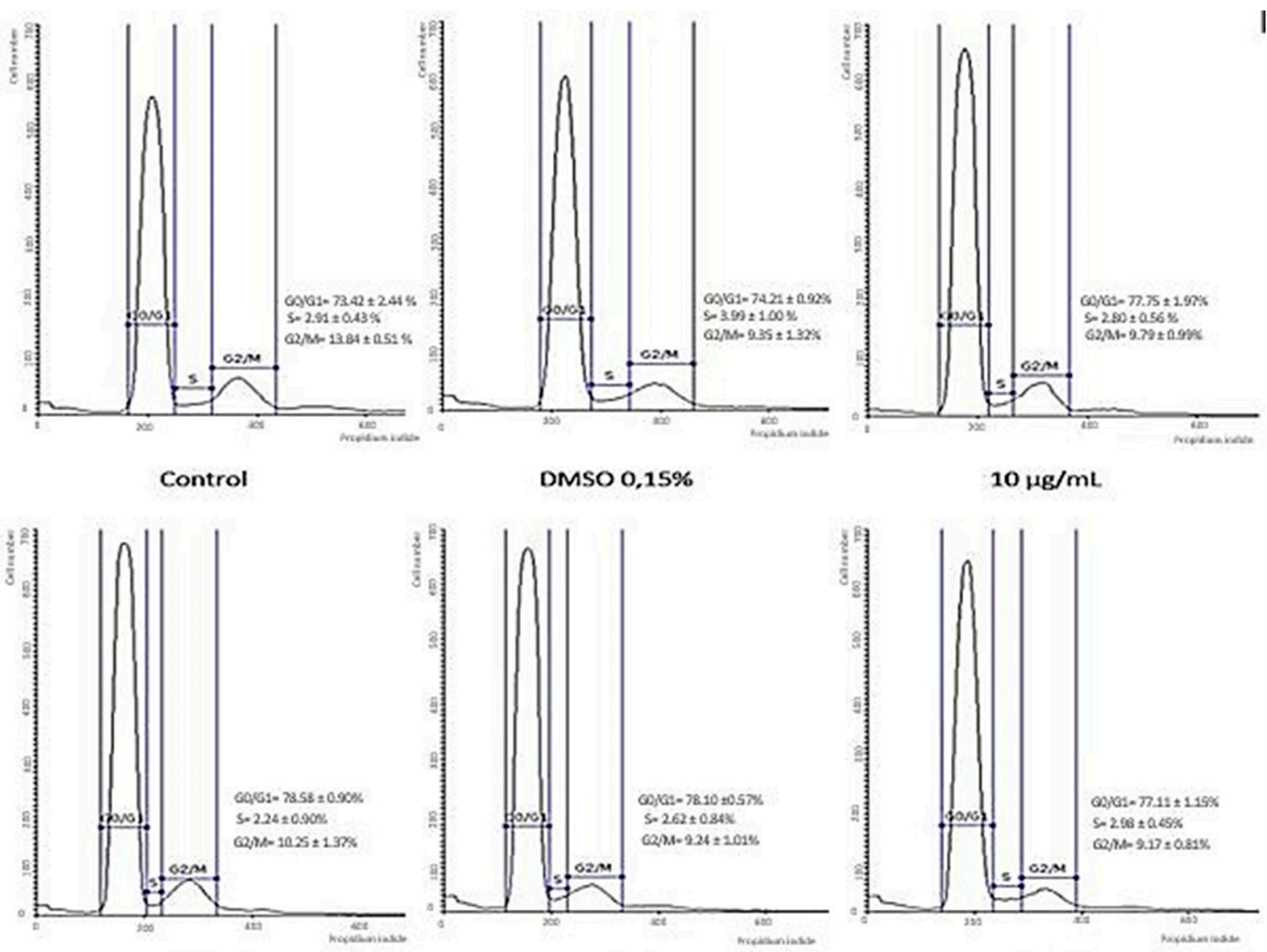

$25 \mu \mathrm{g} / \mathrm{mL}$.

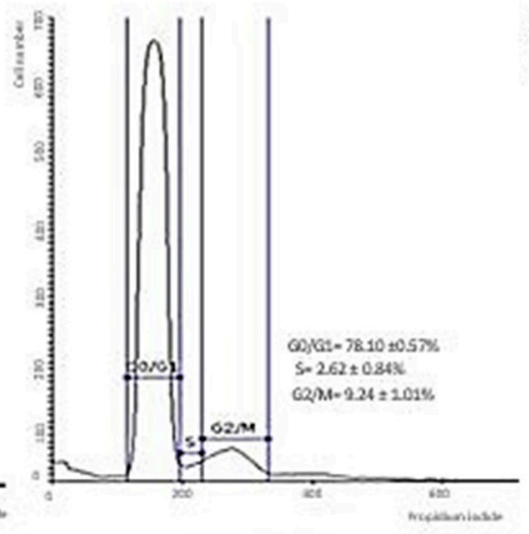

$50 \mu \mathrm{g} / \mathrm{mL}$

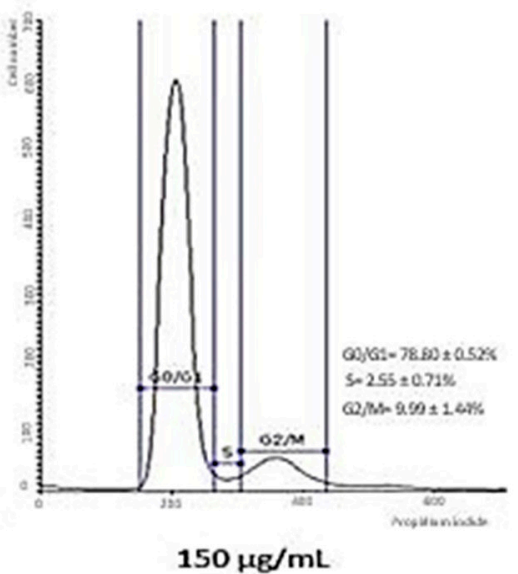

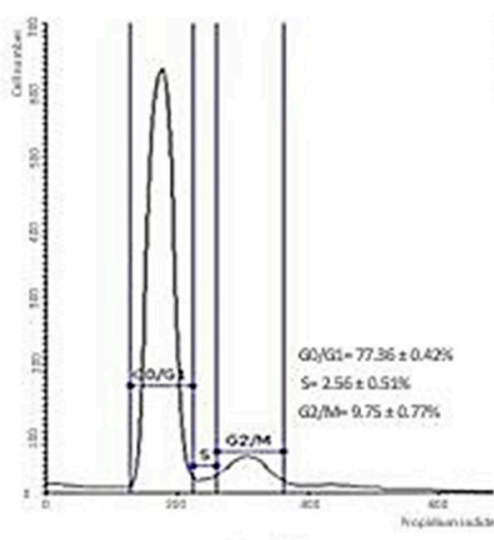

$100 \mu \mathrm{g} / \mathrm{mL}$

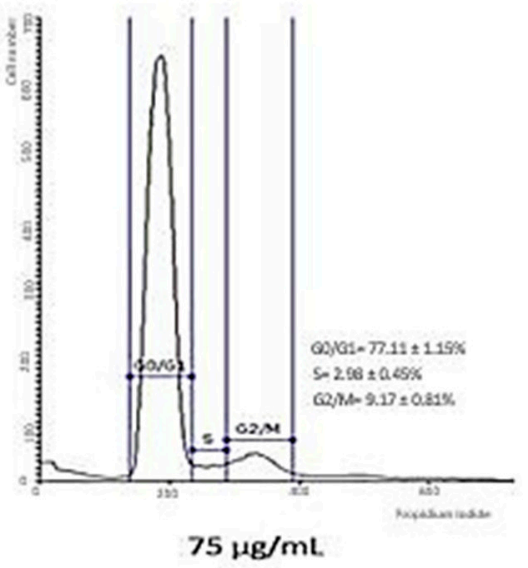

$75 \mathrm{\mu g} / \mathrm{mL}$

Figure 6. Cell cycle histograms determined by flow cytometry. Effects of Pg extract (10, 25, 50, 75, 100, and $150 \mu \mathrm{g} / \mathrm{mL}) \mathrm{on}$ cell cycle phases (G0/G1, S, and G2/M) after $72 \mathrm{~h}$ exposure to Pg extract for A549 human lung adenocarcinoma cell line. Results are expressed as cell viability percentage (\%) related to the control cells. 


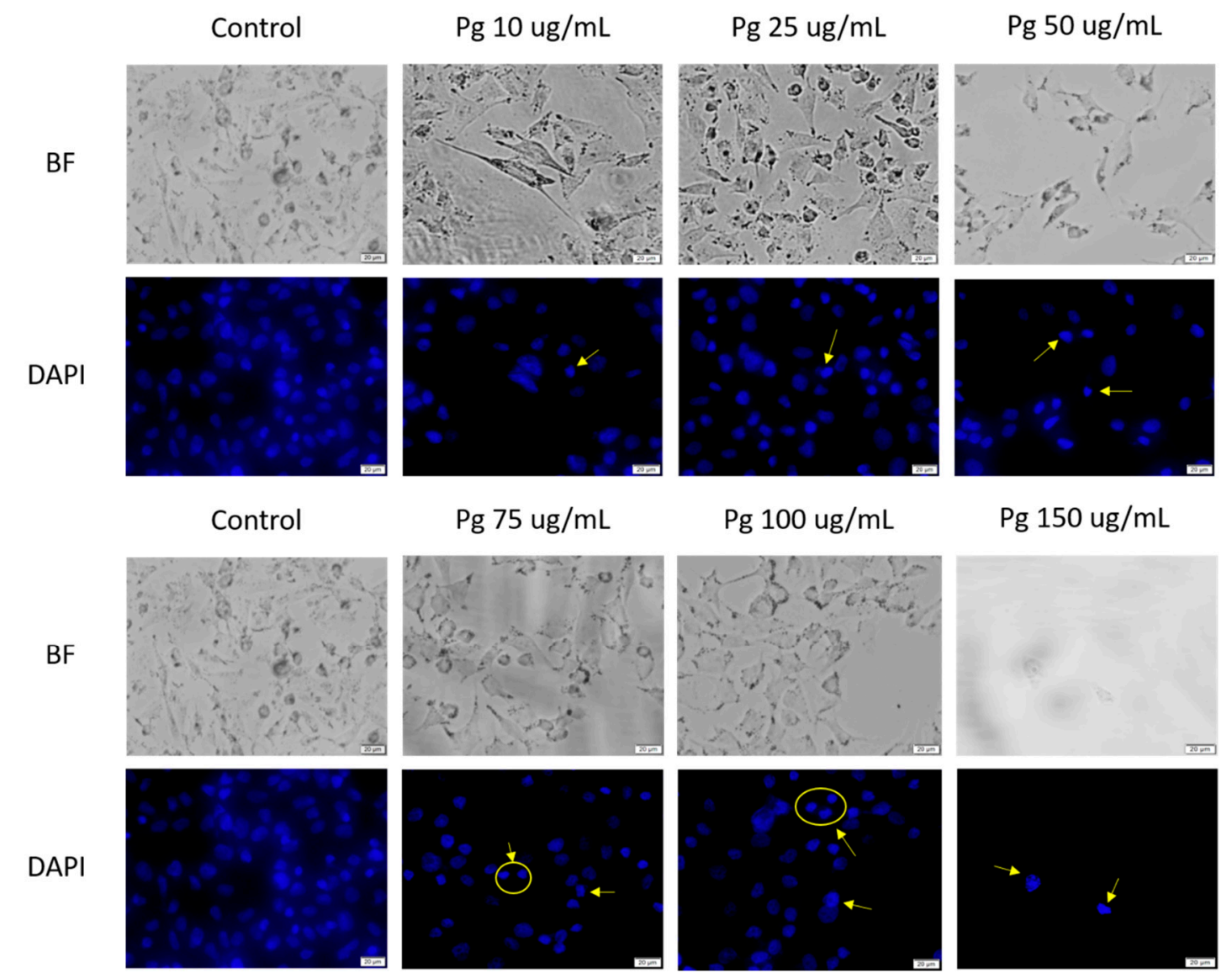

(a)

(b)

Figure 7. A549 human lung adenocarcinoma cells treated with Pg extract at different concentrations (a) (10, 25 and 50) and (b) $(75,100$, and $150 \mu \mathrm{g} / \mathrm{mL})$, for $72 \mathrm{~h}$-DAPI staining was performed for apoptotic morphological characteristics; $\mathrm{BF}=$ bright field microscopy. The scale bars represent $20 \mu \mathrm{m}$.
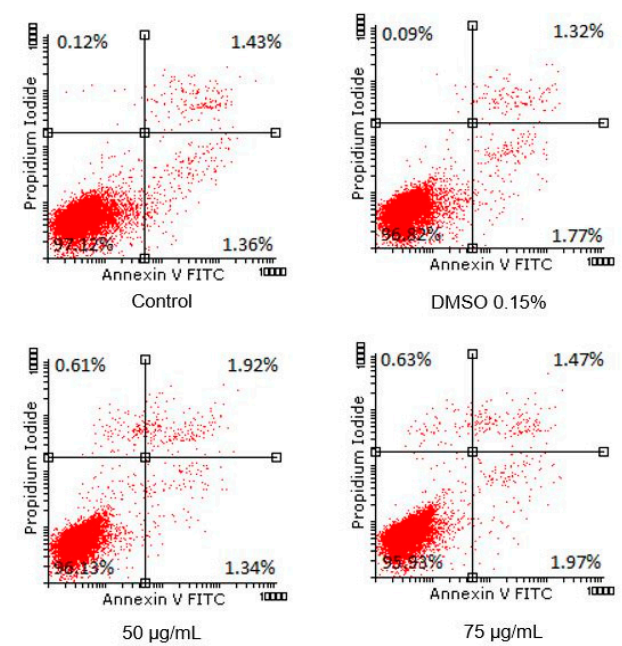

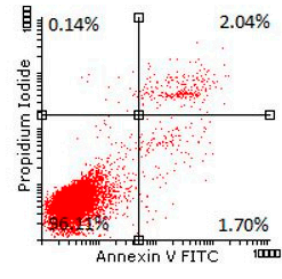

$10 \mu \mathrm{g} / \mathrm{mL}$

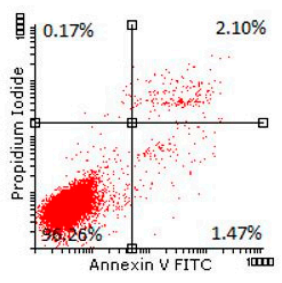

$100 \mu \mathrm{g} / \mathrm{mL}$

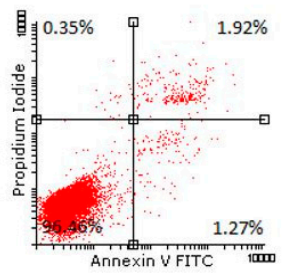

$25 \mu \mathrm{g} / \mathrm{mL}$

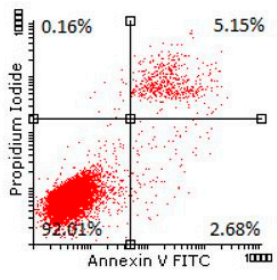

$150 \mu \mathrm{g} / \mathrm{mL}$

Figure 8. Representative dot-plots. Viability of A549 human lung adenocarcinoma cell line using Annexin V/PI analysis. 

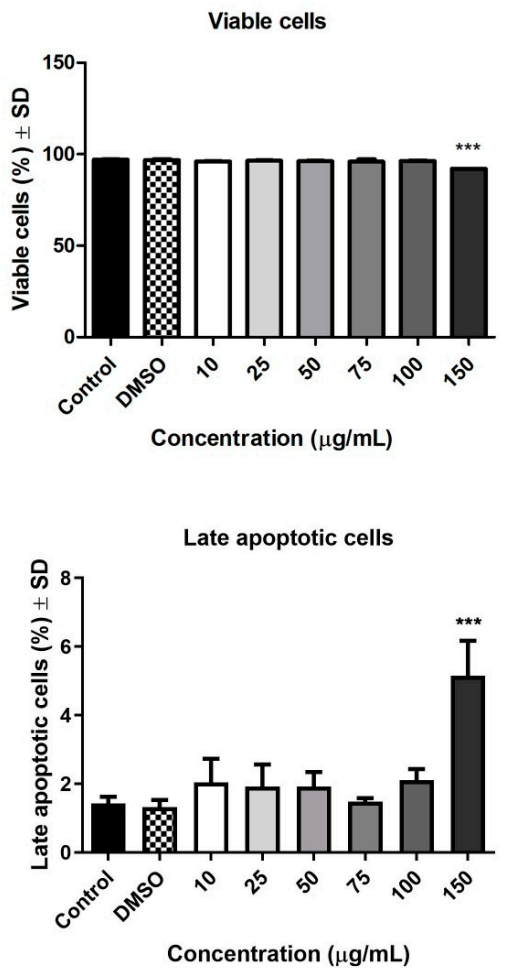
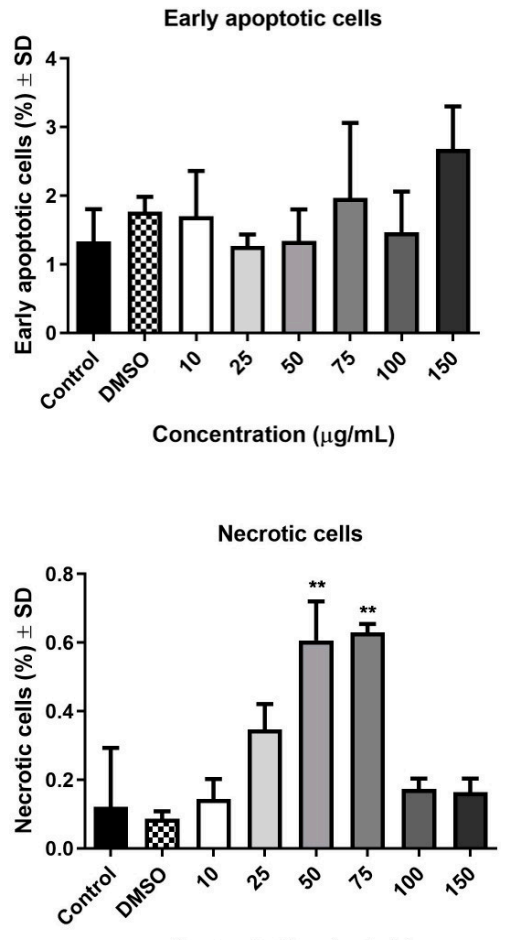

Concentration $(\mu \mathrm{g} / \mathrm{mL})$

Figure 9. The pro-apoptotic potential of Pg extract $(10,25,50,75,100$, and $150 \mu \mathrm{g} / \mathrm{mL}$ ) on A549 human lung adenocarcinoma cells. The bar graphs are expressed as the percentage (\%) of viable cells, early apoptotic cells, late apoptotic cells, and necrotic cells related to control cells. ${ }^{* *} p<0.01$, *** $p<0.001$.

\subsection{Determination of the Cytotoxic Potential by LDH Release}

To assess the cytotoxic potential of Pg extract, the lactate dehydrogenase assay was conducted. After $72 \mathrm{~h}$ of stimulations, the cytotoxicity assessment indicated that Pg extract increased in a dose-dependent manner the release of lactate dehydrogenase. Figure 10 depicts the effect of Pg on the lung tumor cells. A significant cytotoxic effect was obtained at $25 \mu \mathrm{g} / \mathrm{mL}(11.3 \pm 0.9 \%), 50 \mu \mathrm{g} / \mathrm{mL}(13.1 \pm 1 \%), 75 \mu \mathrm{g} / \mathrm{mL}(18 \pm 1.4 \%)$, and $100 \mu \mathrm{g} / \mathrm{mL}$ $(21.7 \pm 1.6 \%)$. At the highest tested dose $(150 \mu \mathrm{g} / \mathrm{mL})$, the cytotoxic rate was $7.8 \pm 1.3 \% \mathrm{vs}$. control $(2.9 \pm 0.8 \%)$.

\section{A549- human lung adenocarcinoma}

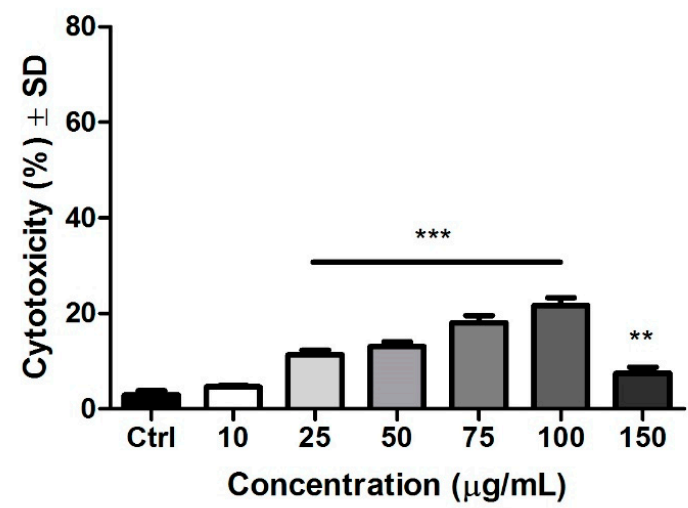

Figure 10. $\operatorname{Pg}(10,25,50,75,100$, and $150 \mu \mathrm{g} / \mathrm{mL})$ cytotoxic effect on A549 human lung adenocarcinoma cells after $72 \mathrm{~h}$ stimulation. The data are expressed as cytotoxicity percentage (\%) related to the control cells. One-way ANOVA test and Dunnett's multiple comparison post-test were employed for comparison among groups $\left({ }^{* *} p<0.01,{ }^{* * *} p<0.001\right.$ vs. Control). 


\section{Discussion}

The Salicaceae family includes the Populus and Salix genera, which are widely distributed in Northern temperate regions. Tawfeek et al. reported that the Salicaceae family contains different phytoconstituents such as flavonoids, phenolic glycosides (salicin, tremuloidin, and tremulacin), phenolic acids ( $p$-hydroxybenzoic, salicylic, gentisic, vanillic, p-anisic, gallic, and protocatechuic acids, but also p-coumaric, isoferuolic, feruolic, and caffeic acids), anthocyanins, procyanidins, organic acids, fatty acids, and volatile compounds (terpenes and monoterpenes) [41]. The literature reported that Caesaria arborea L. leaves' methanolic extract (Salicaceae family) contains diterpene, flavonoids, phenolics, and glycoside derivatives (flavonoid-3-O-glycosides) [42]. A recent study highlights that the two genera from the Salicaceae family (Populus and Salix) contain mostly secondary compounds. In this regard, the authors characterized the chemical composition of leaves and fruits from two different species, namely Salix acmophylla L. and Populus euphratica L. Using GS-MS, the group have shown that the phytochemicals in both species varied between phenols (salicin, coumarin, $p$-xylene, and styrene), fatty acids (linolenic acid, 1-octacosanol, and oleic acid amide), amino acids (thymine, isobutyl nitrite, and sebacic acid), alkanes, alkaloids, esters, and carbohydrates (sucrose, hexose) [43]. Djouossi et al. showed that the methanol extract of the leaves of Oncoba spinosa Forssk. (Salicaceae family) includes flavonoids such as kaempferol, apigenin-7-O- $\beta$-D-glucuronopyranoside, quercetin, quercetin 3-O- $\beta$-D-galactopyranoside, and also quercetin 3-O- $\alpha$-L-rhamnopyranosyl [44]. Pg extract evaluated in this study had a high number of phenolic compounds (chicoric acid, apigenin-glucuronide, chrysoeriol-glucuronide, tremuloidin, dihydroxybenzoic acid, protocatechuic acid, 3-caffeoylquinic acid, 5-caffeoylquinic acid, caffeic acid, salicin, pinostrobin, and tremulacin). Results obtained in this study regarding the phytochemical composition of the ethanolic extract of Romanian poplar buds are in line with those reported by other authors.

Poplar is known to be an efficient bio-accumulator of soil chemicals, allowing its use to remedy the soil of toxic elements; because of this property, it was the subject of many studies [45-47]. However, its ability to bioaccumulate raises concerns about the possible adverse health effects of products derived from this plant that are ingested by humans, in various forms, used for medicinal purposes. The active principles are the ones generally sought and highlighted, but from the point of view of the contained elements, it is important to determine the concentration of trace elements $(\mathrm{Mg}, \mathrm{Fe}, \mathrm{Mn}, \mathrm{Cu}$, and $\mathrm{Zn}$ ) and potentially toxic elements ( $\mathrm{Al}, \mathrm{Co}, \mathrm{Cr}, \mathrm{As}, \mathrm{Cd}$, and $\mathrm{Pb}$ ). Results obtained for the screened extract are compared with the maximum allowed doses for herbal supplements, but also with the recommended values for drinking water (for the elements where there are no recommendations for herbal medicines). Assuming that the daily water intake is $2 \mathrm{~L}$, in this way, we can estimate a maximum allowable concentration per day, and we can compare it with the concentration obtained in the alcoholic extract of poplar buds. Additionally, for trace elements, the recommended daily dose is used comparatively. There are several regulations stipulated by WHO guidelines for assessing the quality of herbal medicines with reference to the contaminants such as $\mathrm{As}, \mathrm{Cd}$, and $\mathrm{Pb}$. The National Sanitation Foundation recommends that a finished dietary supplement (such as poplar buds ethanolic extract) may bring a maximum intake of $0.01 \mathrm{mg} /$ day of As, $0.006 \mathrm{mg} /$ day of $\mathrm{Cd}, 0.02 \mathrm{mg} /$ day of $\mathrm{Pb}$, and $0.02 \mathrm{mg} /$ day of $\mathrm{Cr}$ [48]. The first important step for a phytopharmaceutical product is the validation of being free of toxic metals. As is a toxic metal, and chronic exposure is associated with neuropathy, developmental disabilities, decreased IQ, numerous skin disorders, hypertension, and cancer of the skin, lungs, bladder, and kidney [49]. In the extracts, it has a concentration below the detection limit, namely below $13.2 \mu \mathrm{g} / \mathrm{L}$. Moreover, knowing this, the As concentration from the Pg ethanolic extract does not represent a reason for concern and does not contribute to the accumulation process. Lead $(\mathrm{Pb})$ is another toxic metal. Enhanced $\mathrm{Pb}$ concentration in blood affects cognitive performance, behavior, and postnatal growth and reduces hearing capacity in children and infants. In adults, $\mathrm{Pb}$ causes kidney, cardiovascular, fertility, and central 
nervous system disorders. WHO accepted for an adult a daily $\mathrm{Pb}$ intake of up to $7 \mu \mathrm{g} / \mathrm{kg}$ body weight or $490 \mu \mathrm{g}$ of $\mathrm{Pb}$ [50]. In Pg ethanolic extracts, $\mathrm{Pb}$ concentration was below the detection limit set at $7.4 \mu \mathrm{g} / \mathrm{L}$. Knowing the $\mathrm{WHO}$ recommendations [48] of a maximum of $10 \mathrm{ppm}$ for herbal supplements, it can be assessed that the ethanolic extract can be used safely.

It is known that for nonsmokers, diet is the major source of cadmium (Cd), which is a food-chain contaminant. Chronic $\mathrm{Cd}$ exposure is usually associated with chronic kidney disease, cardiovascular disease, diabetes, osteoporosis, and cancer [51]. Cd principally accumulates in the kidneys, but blood Cd levels show a correlation with urinary Cd levels, and they could thus be of value in risk assessment [52]. Cd was detected in a concentration of $0.019 \mu \mathrm{g} / \mathrm{g}$, the equivalent of $0.019 \mathrm{ppm}$, less than the permitted limits by WHO [46] of $0.3 \mathrm{ppm}$ for herbal supplements. Cobalt is an important oligoelement, widely dispersed in the environment in low concentrations. Most people are exposed to small amounts of cobalt by consuming contaminated drinking water or food or inhaling contaminated air. The only known biological function of cobalt is its role as a metal component of vitamin B12, also named cyanocobalamin [53]. Exposure of humans and animals to levels of cobalt normally found in the environment is not harmful. It is known that water quality standards for cobalt (Co) have not been developed for the European Union or United States [54]. From this point of view, Co concentration in poplar buds' ethanolic extract was under the detection limit $(5.4 \mu \mathrm{g} / \mathrm{L})$, being safe to use as a therapeutic remedy.

Primula officinalis $\mathrm{L}$. flower ethanolic extract presented a similar copper $(\mathrm{Cu})$ concentration $(6.9 \mathrm{mg} / \mathrm{kg})$ [29] as Pg extract from the present study: $6.66 \mu \mathrm{g} / \mathrm{g}$. Usually, there is less $\mathrm{Cu}$ intake, so any $\mathrm{Cu}$ supplementation in food is good. Accumulation of nickel in the body through chronic exposure from highly nickel-polluted environments may be responsible for cancer of the respiratory tract, lung fibrosis, cardiovascular, and kidney diseases. Natural nickel deficiency does not easily occur, as it is found in abundance in food [55]. In Pg ethanolic extract, the nickel concentration was found to be $3.28 \mu \mathrm{g} / \mathrm{g}$, a higher concentration compared to the summarized concentrations by Pohl et al. [56] for herbal tea infusions or decoctions: $0.0003-0.42 \mu \mathrm{g} / \mathrm{mL}$, but still low compared to WHO recommendations [57] for drinking water: $20 \mu \mathrm{g} / \mathrm{L} \mathrm{Ni}$. Aluminum (Al) is present in processed and unprocessed foods and drinks, but its low absorption from the intestinal tract and removal in urine via the kidneys make the levels of Al present in the body remain low, without concern for people with normal kidney function. Al can cross the blood-brain barrier, so it can accumulate in the brain. For example, neurotoxic effects have been observed in animal experiments at doses above $200 \mathrm{mg} / \mathrm{kg}$ bw/day; therefore, based on the available data, the European Food Safety Authority (EFSA) carried out a safety evaluation and did not consider exposure to $\mathrm{Al}$ to constitute a risk for developing Alzheimer's disease. Additionally, the tolerable weekly intake (TWI) of $1 \mathrm{mg} / \mathrm{kg}$ body weight (bw)/week was increased, because of their confidence in the risk assessment to $2 \mathrm{mg} / \mathrm{kg} \mathrm{bw} /$ week [58]. In Pg ethanolic extract, aluminum reaches a concentration of $2109.87 \mu \mathrm{g} / \mathrm{g}$, equivalent to $2.1 \mathrm{mg} / \mathrm{g}$. This is not alarming, because it is reported that in the case of drug administration, the normal average intake may reach 50-1000 $\mathrm{mg} /$ day [59]. Additionally, some in vitro methods suggest that $\mathrm{Al}$ from a tea infusion is potentially available for absorption at only $4.8 \%$. Moreover, only $0.37 \%$ is orally bioavailable, established by in vivo experiments [60]. Chromium is a potentially toxic element, but keeping it under a safe limit is a major challenge because of the metal bioaccumulation in medicinal plants, consequently leading to human health exposure. Nirola et al. [61] mention that the acceptable Cr concentration for raw medicinal plants used further for their therapeutic values is up to $10 \mu \mathrm{g} / \mathrm{g}$. A manganese $(\mathrm{Mn})$ concentration of $0.59 \mu \mathrm{g} / \mathrm{g}$ and a chromium $(\mathrm{Cr})$ concentration of $0.79 \mu \mathrm{g} / \mathrm{g}$ do not have a large contribution to the dietary intake, because the recommended dietary allowances (RDA) are $2.30 \mathrm{mg} \mathrm{Mn/day/person} \mathrm{and} 35 \mu \mathrm{g} \mathrm{Cr} /$ day/person for males [62]. Even the WHO recommendations [56] for drinking water provide a maximum of $50 \mu \mathrm{g} / \mathrm{L}$ $\mathrm{Mn}$, thus being higher than the one obtained for the plant extract in this study. Iron (Fe), an important trace element, is a vital nutrient for the human body. It takes part in a variety of 
cellular events and activates many enzymes responsible for the synthesis of collagen, amino acids, neurotransmitters, and hormones. The iron content in the body must be equilibrated because any disequilibrium like excess or deficit may have harmful consequences. The poplar buds' ethanolic extract contains $39.00 \mu \mathrm{g} / \mathrm{g}$. This value is small, and considering that $\mathrm{Fe}$ is classified among the poorly extractable elements (below $20 \%$ ) and that the TDI for an adult is $0.7 \mathrm{mg} / \mathrm{kg}$ body weight (49 $\mathrm{mg}$ for an adult) [60], the Fe intake from the extract is negligible. This conclusion is certificated by the comparison with the contents of a survey of plant iron content, mentioned for plants like Tectona grandis L.f., Amaranthus spinosus L., and Stylosanthes erecta P. Beauv., which contained the highest iron contents: 2666, 2366, and $2066 \mu \mathrm{g} / \mathrm{g}$, respectively [63]. Zinc (Zn) is a trace metal, one of the metals that accumulates even in high concentrations in the plant, in the phytoremediation process. In this manner, Guerra et al. [64] reported that for P. nigra clones, zinc ( $\mathrm{Zn}$ ) leaf concentrations ranged within the interval 569-935 $\mu \mathrm{g} / \mathrm{g}$. In the present study, the detected $\mathrm{Zn}$ concentration $(14.84 \mu \mathrm{g} / \mathrm{g})$ represents a low intake of $\mathrm{Zn}$, but at the same time, it is risk-free if up to $88.8 \%$ can be extracted from the plant by ethanolic extraction [29].

Thus, based on experimental outcomes, it can be concluded that the Pg ethanolic extract has a low contribution to trace elements in dietary intake, but the most valuable conclusion is regarding its safety; we can highlight that Pg extract does not produce any harmful effect of metal toxicity during its therapeutic application.

As is already known, cancer is one of the most frequent diseases caused by genetic alterations in cells [65]. Lung cancer is one of the most common causes of death in both men and women worldwide [66]. Many natural compounds have been shown to be effective in the management of various types of cancer, including lung cancer. Different preclinical studies have shown the antitumor activity of various medicinal plant extracts against lung cancer. Melissa oficinalis L. was reported with a potential antitumoral effect against various cancer cell lines, one of the most representative activities being elicited on the A549 lung cancer cell line. It was demonstrated that the $\mathrm{EO}$ (essential oils) at different doses $(0,5,20,100,250,500$, and $1000 \mu \mathrm{g} / \mathrm{mL})$ possess a high potency to inhibit proliferation of lung cancer cells in a dose-independent manner when compared to a positive control $(20 \mu \mathrm{g} / \mathrm{mL}$ Toxol-Paclitaxel (plant-derived chemotherapeutic anti-cancer drug from Taxus brevifolia)), indicating that an optimal dose is more relevant than a maximally tolerated one [67]. Miladi et al. examined the EOs of Rosmarinus officinalis L. and Tymus vulgaris L. for their in vitro cytotoxic activity against A549 human lung cancer. They revealed that after 48 and $72 \mathrm{~h}$ exposure, EO obtained from Rosmarinus officinalis L. strongly inhibited the proliferation of A549 cells with an $\mathrm{IC}_{50}=8.50 \pm 0.01 \mu \mathrm{g} / \mathrm{mL}$ and EO obtained from Tymus vulgaris $\mathrm{L}$. with an $\mathrm{IC}_{50}=10.50 \pm 0.01 \mu \mathrm{g} / \mathrm{mL}$, respectively [68]. Mohammad-Hossein et al. investigated the properties of the ethanolic extract of Thymus kotschyanus L. against A549 lung cancer cell lines. Results indicated that Thymus kotschyanus L. extract $(10,5,2.5,1.25$, $0.63,0.31,0.15$, and $0.08 \mathrm{mg} / \mathrm{mL}$ ) inhibited lung cancer cell growth and viability in a doseand time-dependent manner [69]. A recent study highlights that nargenin nanoemulsion (a flavonoid mainly found in citrus and also grapefruit) presented a high efficiency against A549 human lung cancer cell lines. The nanoemulsion $(0.39,1.56,6.25,25$, and $100 \mu \mathrm{g} / \mathrm{mL})$ elicited a concentration-dependent cytotoxicity in A549 lung cancer cells and conducted cell arrest in the G2/M and sub-G1 phases. The authors also concluded that nargenin nanoemulsion increased the caspase- 3 and pro-apoptotic Bax protein while decreasing the expression of the anti-apoptotic protein Bcl2 [70]. Poofery et al. tested in vitro three tropical medicinal plants originated from Thailand, Bridelia ovata Decne (ethyl acetate extract), Croton oblongifolius Roxb. (ethyl acetate extract), and Erythrophleum succirubrum Gagnep (ethyl acetate extract and ethanol extract) against A549 human lung cancer cell lines. Cytotoxicity and apoptotic assays showed that all four extracts possessed potential anticancer activity against lung cancer, but the most effective was the ethanolic extract of E. succirubrum [71]. Remaining in the field of tropical plants, it was shown that Ocimum sanctum L. (originated from Indonesia) elicited an in vitro anticancer effect against A549 cells. The ethanolic extract (50,70,100, or $200 \mathrm{ug} / \mathrm{mL}$ ) significantly decreased the viability of A549 cells. 
Moreover, at the concentration of $100 \mu \mathrm{g} / \mathrm{mL}$, it induced the most severe cytotoxicity and apoptosis rate, followed by up-regulation of reactive oxygen species (ROS) and caspase-3 expression and decreased the anti-apoptotic protein Bcl-2 [72]. Yun Tsai et al. indicated that 6-Gingerol (found in Zingiber officinale L.) at different concentrations (20-80 $\mu \mathrm{M}$ ) suppressed A549 cells' proliferation in vitro. Moreover, it significantly reduced the tumor size in vivo by administering 0.25 and $0.5 \mathrm{mg} / \mathrm{kg} /$ day 6-gingerol to BALB/cNude mice subcutaneously inoculated with A549 tumor cells. Experimental data confirmed that 6-Gingerol increased the expressions of Beclin-1, LC3 I, LC3 II, NCOA4, and TfR1 and down-regulated the expression of USP14, FTH1, GPX4, and ATF4 [73]. Another study demonstrated that carvacrol is a potential candidate for lung cancer therapy. In this regard, the authors tested an oil-in-water carvacrol nanoemulsion $(5-100 \mu \mathrm{g} / \mathrm{mL})$ against doxorubicin-resistant A549 lung carcinoma cells, in vitro as well as in vivo, using an experimental animal model of lung cancer (male nude mice and injected with A549 cells subcutaneously). The in vitro results showed that carvacrol nanoemulsion induced apoptosis and can inhibit proliferation. This was highlighted by an increased level of Bax, caspase 3 and 9 and cytochrome C, cell cycle arrest, decreased CDK2, CDK4, CDK6, Cyclin E, Cyclin D1, and increased p21 protein expression [74].

The group of Yang et al. showed that kukarione, a flavonoid isolated from Sophora flavescens Aiton, presented potential antitumor activity against lung cancer both in vitro as well as in vivo. Using different in vitro assays, the authors concluded that kukarione at concentrations of $5,10,15$, and $20 \mu \mathrm{g} / \mathrm{mL}$ inhibited the proliferation of A549 cells $\left(\mathrm{IC}_{50}>50 \mu \mathrm{g} / \mathrm{mL}\right)$ and induced apoptosis at the highest concentrations. Moreover, kukarione administering intraperitoneally at doses of 20 and $40 \mathrm{mg} / \mathrm{kg} /$ day inhibited the growth of pulmonary cancer (A549 xenograft mouse models athymic BALB/c mice) by up-regulating the pro-apoptotic proteins cleaved-caspase-3, cleaved-caspase- 9 , and Bax and by down-regulating the antiapoptotic Bcl-2 expression [75].

The literature also reported that some vegetal products from the Salicaceae family, same as black poplar buds, presented antitumor activity against different lung cancer cell lines. Populus alba L. (also known as white poplar), which has similar properties to Populus nigra L., is an example in this direction. Sevgi Gezici et al. described that the EOs obtained from the leaves and flowers of white poplar exhibited a significant antiproliferative effect against A549 (lung adenocarcinoma), MCF7 (breast adenocarcinoma), and $\mathrm{H} 1299$ (human non-small cell lung cancer) cell lines with $\mathrm{IC}_{50}$ values ranging from 12.05 to $28.16 \mu \mathrm{g} / \mathrm{mL}$ [76]. Pereira et al. demonstrated that Casearia arborea L.'s (Salicaceae family) essential oils obtained from the fresh leaves by hydro-distillation present a significant cytotoxic effect against the A549 lung cancer cell line. Using the WST-1 assay, it was concluded that concentrations ranging from 0.5 to $20 \mu \mathrm{g} / \mathrm{mL}$ reduce the proliferation of A549 cells (EC50 at $4.0 \mu \mathrm{g} / \mathrm{mL}$ ) when compared with the positive control (Doxorubicin $0.01358 \mu \mathrm{g} / \mathrm{mL}$ ) [77]. A recent study, conducted by Li Junya et al., showed that Chinese propolis, especially originated from poplar (Populus sp.) at concentrations ranging in the interval of 25,50, and $100 \mu \mathrm{g} / \mathrm{mL}$ significantly inhibited the MDA-MB-231 human breast cancer cell line proliferation, migration, and also invasion [78]. The present study showed that Pg extract produced a dose-dependent decrease of A549 lung adenocarcinoma cells viability and migration. Furthermore, at the highest tested concentration, a slight proapoptosis effect was noticed. The percentage of early apoptotic cells was increased from $1.34 \% \pm 0.33$ (control cells) to $2.68 \% \pm 0.62(150 \mu \mathrm{g} / \mathrm{mL} \mathrm{Pg})$ after $72 \mathrm{~h}$ of incubation with $\mathrm{Pg}$. A cytotoxic effect quantified by the amount of LDH release was also observed following stimulation with Pg extract. At the highest tested concentration $(150 \mu \mathrm{g} / \mathrm{mL})$, a decrease in LDH release was observed, phenomena previously reported for other compounds that induce cell cycle arrest. LDH release can be low at high concentrations tested because the tumor cells do not express proliferative effects [34,79]. Even though LDH release was lower at the highest concentration tested, Pg extract elicited a cytotoxic effect on A549 lung cancer cells, also shown by the images taken following DAPI staining. 


\section{Conclusions}

The study concludes that Pg ethanolic extract has a low contribution to trace elements in dietary intake, but the most valuable conclusion is regarding its safety, namely, the tested Pg extract does not produce any harmful effect of metal toxicity during therapeutic application. In the set experimental conditions, Pg extract elicited in a dose-dependent manner antiproliferative and slight pro-apoptotic and cytotoxic potential against the A549 cancer cell line. Further studies need to be conducted that involve an animal model of lung cancer in order to have a full picture of the possible therapeutic potential and benefit in the management of lung cancer.

Author Contributions: Conceptualization, B.K., I.Z.P. and C.D.; methodology, B.K., I.Z.P., D.H., M.N.S., Z.D., E.-A.M., S.S. and A.I.; software, B.K., I.Z.P., D.H., M.N.S., Z.D., E.-A.M., S.S. and A.I.; validation, C.A.D., Z.D. and C.D.; formal analysis, B.K., I.Z.P., D.H., M.N.S., Z.D., E.-A.M., S.S, and A.I.; investigation, B.K., I.Z.P., D.H., M.N.S., Z.D., E.-A.M., S.Ș. and A.I.; resources, C.A.D., I.Z.P. and C.D.; data curation, B.K., I.Z.P., D.H., M.N.S., Z.D., E.-A.M., S.S. and A.I.; writing—original draft preparation, B.K., I.Z.P., D.H., M.N.S., Z.D., E.-A.M., S.Ș. and A.I.; writing-review and editing, C.A.D. and C.D.; visualization, C.A.D., I.Z.P. and C.D.; supervision, C.D.; project administration, I.Z.P. and C.D.; funding acquisition, I.Z.P. and C.D. All authors have read and agreed to the published version of the manuscript.

Funding: This research was funded by "Victor Babes" University of Medicine and Pharmacy, grant number 3POSTDOC $/ 1238 / 2020$.

Institutional Review Board Statement: Not applicable.

Informed Consent Statement: Not applicable.

Data Availability Statement: All data used to support the findings of this study are included within the article.

Conflicts of Interest: The authors declare no conflict of interest.

\section{References}

1. Petrovska, B.B. Historical review of medicinal plants usage. Pharmacogn. Rev. 2012, 6, 1-5. [CrossRef] [PubMed]

2. Kennedy, O.W.; Wightman, L.E. Herbal Extracts and Phytochemicals: Plant Secondary Metabolites and the Enhancement of Human Brain function. Adv. Nutr. 2011, 2, 32-50. [CrossRef]

3. Michel, J.; Nur Zahirah, A.R.; Khairana, H. A Review on the Potential Use of Medicinal Plants From Asteraceae and Lamiaceae Plant Family in Cardiovascular Diseases. Front. Pharmacol. 2020, 11, 852. [CrossRef] [PubMed]

4. Aye, M.M.; Aung, H.T.; Sein, M.M.; Armijos, C. A Review on the Phytochemistry, Medicinal Properties and Pharmacological Activities of 15 Selected Myanmar Medicinal Plants. Molecules 2019, 24, 293. [CrossRef] [PubMed]

5. Azab, A.; Nassar, A.; Azab, A.N. Anti-Inflammatory Activity of Natural Products. Molecules 2016, 21, 1321. [CrossRef]

6. Stănescu, U.; Hăncianu, M.; Cioancă, O.; Aprotosoaie, A.C.; Miron, A. Plante medicinale de la A la Z, a III-a, ed.; Revizuită Si adăugită; Editura Polirom: Iaşi, Romania, 2018; ISBN 978-973-46-7240-0.

7. Zong, D.; Gan, P.; Zhou, A.; Zhang, Y.; Zou, X.; Duan, A.; Song, Y.; He, C. Plastome Sequences Help to Resolve Deep-Level Relationships of Populus in the Family Salicaceae. Front. Plant Sci. 2019, 10, 5. [CrossRef] [PubMed]

8. Alcalde-Eon, C.; García-Estévez, I.; Rivas-Gonzalo, J.; Rodríguez de la Cruz, D.; Escribano, T. Anthocyanins of the anthers as chemotaxonomic markers in the genus Populus L. Differentiation between Populus nigra, Populus alba and Populus tremula. Phytochemistry 2016, 128. [CrossRef]

9. Hage, S.; Morlock, G.E. Bioprofiling of Salicaceae bud extracts through high-performance thin-layer chromatography hyphenated to biochemical, microbiological and chemical detections. J. Chromatogr. A 2017, 1490, 201-211. [CrossRef]

10. Yang, S.; Zhou, Y.; Ye, J.; Fan, G.; Peng, L.; Pan, S. Effects of poplar buds as an alternative to propolis on postharvest diseases control of strawberry fruits. J. Sci. Food Agric. 2016, 96, 2136-2141. [CrossRef] [PubMed]

11. Pavlovic, R.; Borgonovo, G.; Leoni, V.; Giupponi, L.; Ceciliani, G.; Sala, S.; Bassoli, A.; Giorgi, A. Effectiveness of Different Analytical Methods for the Characterization of Propolis: A Case of Study in Northern Italy. Molecules 2020, 25, 504. [CrossRef]

12. Lee, Y.S.; Cui, C.B.; Kim, J.K.; Bae, Y.S.; Lee, J.Y.; Kang, I.J.; Lim, S.S. Inhibitory Effect of Populoside from the Bark of Populus nigra on Aldose Reductase. J. Korean Soc. Appl. Biol. Chem. 2010, 53, 729-733. [CrossRef]

13. Stănescu, U.; Hăncianu, M.; Gîrd, C.E. Farmacognozie. Produse Vegetale cu Substanțe Bioactive; Editura Polirom: Iasi, Romania, 2020; ISBN 978-973-46-7996-6.

14. Jerkovic, I.; Mastelic, J. Volatile compounds from leaf-buds of Populus nigra L. (Salicaceae). Phytochemistry 2003, 63, 109-113. [CrossRef] 
15. Isidorov, V.A.; Vinogorova, V.T. GC-MS analysis of compounds extracted from buds of Populus balsamifera and Populus nigra. Z. Nat. C J. Biosci. 2003, 58, 355-360. [CrossRef]

16. Cooke, J.E.; Martin, T.A.; Davis, J.M. Short-term physiological and developmental responses to nitrogen availability in hybrid poplar. New Phytol. 2005, 167, 41-52. [CrossRef]

17. Bélanger, A.; Grenier, A.; Simard, F.; Gendreau, I.; Pichette, A.; Legault, J.; Pouliot, R. Dihydrochalcone Derivatives from Populus balsamifera L. Buds for the Treatment of Psoriasis. Int. J. Mol. Sci. 2019, 21, 256. [CrossRef] [PubMed]

18. Merghache, D.; Boucherit-Otmani, Z.; El Haci, I.; Merghachec, S.; Chikhid, I.; Boucherita, K. Antioxidant and antimicrobial activities of algerian Populus nigra L. buds extracts. Braz. J. Pharm. Sci. 2016, 3, 1-8. [CrossRef]

19. Debbache, N.; Atmani, D.; Atmani, D. Chemical analysis and biological activities of Populus nigra, flower buds extracts as source of propolis in Algeria. Ind. Crops Prod. 2014, 53, 85-92. [CrossRef]

20. Mainar, A.M.; Langa, E.; Berrueco, B.; Maestro, C.; Urieta, J.S. Antioxidant Activity of Supercritical Extracts of Populus Buds. In Proceedings of the 11th European Meeting on Supercritical Fluids, Barcelona, Spain, 4-7 May 2008; pp. 2-7.

21. Pandey, K.B.; Rizvi, S.I. Plant polyphenols as dietary antioxidants in human health and disease. Oxid. Med. Cell. Longev. 2009, 2, 270-278. [CrossRef] [PubMed]

22. Uttara, B.; Singh, A.V.; Zamboni, P.; Mahajan, R.T. Oxidative stress and neurodegenerative diseases: A review of upstream and downstream antioxidant therapeutic options. Curr. Neuropharmacol. 2009, 7, 65-74. [CrossRef]

23. Vlietinck, A.; Pieters, L.; Apers, S. Legal requirements for the quality of herbal substances and herbal preparations for the manufacturing of herbal medicinal products in the European union. Planta Med. 2009, 75, 683-688. [CrossRef] [PubMed]

24. Gasser, U.; Klier, B.; Kühn, A.V.; Steinhoff, B. Current findings on the heavy metal content in herbal drugs. Pharmeuropa 2009, 2009, 37-50.

25. Bouin, A.S.; Wierer, M. Quality standards of the European Pharmacopoeia. J. Ethnopharmacol. 2014, 158, 454-457. [CrossRef] [PubMed]

26. Okinczyc, P.; Szumny, A.; Szperlik, J.; Kulma, A.; Franiczek, R.; Zbikowska, B.; Krzyzanowska, B.; Sroka, Z. Profile of Polyphenolic and Essential Oil Composition of Polish Propolis, Black Poplar and Aspens Buds. Molecules 2018, 23, 1262. [CrossRef] [PubMed]

27. Dudonné, S.; Poupard, P.; Coutière, P.; Woillez, M.; Richard, T.; Mérillon, J.M.; Vitrac, X. Phenolic Composition and Antioxidant Properties of Poplar Bud (Populus nigra) Extract: Individual Antioxidant Contribution of Phenolics and Transcriptional Effect on Skin Aging. J. Agric. Food Chem. 2011, 59, 4527-4536. [CrossRef]

28. Vardar-Ünlü, G.; Sibel, S.; Unlu, M. Composition and in vitro antimicrobial activity of Populus buds and poplar-type propolis. World J. Microbiol. Biotechnol. 2007, 24, 1011-1017. [CrossRef]

29. Kostic, D.; Mitic, S.; Zarubica, A.; Mitić, M.; Veličković, J.; Randjelović, S. Content of trace metals in medicinal plants and their extracts. Hemijska Industrija. 2011, 65, 165-170. [CrossRef]

30. El-Mahrouk, E.M.; Eisa, E.A.E.; Ali, H.M.; Hegazy, M.A.E.; Abd El-Gayed, M.E.S. Populus nigra as a Phytoremediator for Cd, Cu, and $\mathrm{Pb}$ in Contaminated Soil. BioResources 2020, 15, 869-893. [CrossRef]

31. Hermle, S.; Vollenweider, P.; Günthardt-Goerg, M.; Mcquattie, C.; Matyssek, R. Leaf responsiveness of Populus tremula and Salix viminalis to soil contaminated with heavy metals and acidic rainwater. Tree Physiol. 2007, 7, 1517-1531. [CrossRef]

32. Vollenweider, P.; Menard, T.; Günthardt-Goerg, M.S. Compartmentation of metals in foliage of Populus tremula grown on soils with mixed contamination. I. From the tree crown to leaf cell level. Environ. Pollut. 2011, 159, 324-336. [CrossRef]

33. Danciu, C.; Muntean, D.; Alexa, E.; Farcas, C.; Oprean, C.; Zupko, I.; Bor, A.; Minda, D.; Proks, M.; Buda, V. Phytochemical characterization and evaluation of the antimicrobial, antiproliferative and pro-apoptotic potential of Ephedra alata Decne. hydroalcoholic extract against the MCF-7 breast cancer cell line. Molecules 2019, 24, 13. [CrossRef] [PubMed]

34. Ghițu, A.; Schwiebs, A.; Radeke, H.H.; Avram, S.; Zupko, I.; Bor, A.; Pavel, I.Z.; Dehelean, C.A.; Oprean, C.; Bojin, F.; et al. A Comprehensive Assessment of Apigenin as an Antiproliferative, Proapoptotic, Antiangiogenic and Immunomodulatory Phytocompound. Nutrients 2019, 11, 858. [CrossRef] [PubMed]

35. Danciu, C.; Pavel, I.Z.; Babuta, R.; Ersilia, A.; Oana, S.; Pop, G.; Soica, C.; Dehelean, C.; Radulov, I. Total phenolic content, FTIR analysis, and antiproliferative evaluation of lupin seeds harvest from western Romania. Ann. Agric. Environ. Med. 2017, 24, 726-731. [CrossRef]

36. Danciu, C.; Zupko, I.; Bor, A.; Schwiebs, A.; Radeke, H.; Hancianu, M.; Cioanca, O.; Alexa, E.; Oprean, C.; Bojin, F.; et al. Botanical Therapeutics: Phytochemical Screening and Biological Assessment of Chamomile, Parsley and Celery Extracts against A375 Human Melanoma and Dendritic Cells. Int. J. Mol. Sci. 2018, 19, 3624. [CrossRef]

37. Fecker, R.; Buda, V.; Alexa, E.; Avram, S.; Pavel, I.Z.; Muntean, D.; Cocan, I.; Watz, C.; Minda, D.; Dehelean, C.A.; et al. Phytochemical and Biological Screening of Oenothera Biennis L. Hydroalcoholic Extract. Biomolecules 2020, 10, 818. [CrossRef] [PubMed]

38. Danciu, C.; Cioanca, O.; Watz, F.C.; Hancianu, M.; Racoviceanu, R.; Muntean, D.; Zupko, I.; Oprean, C.; Tatu, C.; Paunescu, V.; et al. Botanical Therapeutics (Part II): Antimicrobial and In Vitro Anticancer Activity against MCF7 Human Breast Cancer Cells of Chamomile, Parsley and Celery Alcoholic Extracts. Anticancer. Agents. Med. Chem. 2021, 21, 187-200. [CrossRef]

39. Diaconeasa, Z.; Iuhas, C.I.; Ayvaz, H.; Rugină, D.; Stanilă, A.; Dulf, F.; Bunea, A.; Socaci, S.A.; Socaciu, C.; Pintea, A. Phytochemical Characterization of Commercial Processed Blueberry, Blackberry, Blackcurrant, Cranberry, and Raspberry and Their Antioxidant Activity. Antioxidants 2019, 8, 540. [CrossRef] 
40. Rubiolo, P.; Casetta, C.; Cagliero, C.; Brevard, H.; Sgorbini, B.; Bicchi, C. Populus nigra L. bud absolute: A case study for a strategy of analysis of natural complex substances. Anal. Bioanal. Chem. 2013, 405, 1223-1235. [CrossRef] [PubMed]

41. Tawfeek, N.; Mahmoud, M.F.; Hamdan, D.I.; Sobeh, M.; Farrag, N.; Wink, M.; El-Shazly Assem, M. Phytochemistry, Pharmacology and Medicinal Uses of Plants of the Genus Salix: An Updated Review. Front. Pharmacol. 2021, 12, 50. [CrossRef] [PubMed]

42. Santos, A.L.; Soares, M.G.; de Medeiros, L.S.; Ferreira, M.J.P.; Sartorelli, P. Identification of flavonoid-3-O-glycosides from leaves of Casearia arborea (Salicaceae) by UHPLC-DAD-ESI-HRMS/MS combined with molecular networking and NMR. Phytochem. Anal. 2021. [CrossRef] [PubMed]

43. Allaway, Z.; Sosa, A. Chemical study in leaf and fruit of some species for Populus and Salix in Diwaniyah governorate using gas chromatography- mass spectrometry (GS-MS). Plant Archives. 2019, 19, 102-111.

44. Djouossi, M.G.; Tamokou, J.D.; Ngnokam, D.; Kuiate, J.R.; Tapondjou, L.A.; Harakat, D.; Voutquenne-Nazabadioko, L. Antimicrobial and antioxidant flavonoids from the leaves of Oncoba spinosa Forssk. (Salicaceae). BMC Compl. Alt. Med. 2015, 15, 134. [CrossRef] [PubMed]

45. Palm, E.; Guidi, N.W.; Mancuso, S.; Azzarello, E. Split-root investigation of the physiological response to heterogeneous elevated Zn exposure in poplar and willow. Env. Exper. Bot. 2020, 183, 104347. [CrossRef]

46. Labancová, E.; Vivodová, Z.; Kučerová, D.; Lišková, D.; Kollárová, K. The cadmium tolerance development of poplar callus is influenced by silicon. Ecotoxicology 2020, 29. [CrossRef]

47. Bardule, A.; Bērtinšs, M.; Buša, L.; Lazdina, D.; Viksna, A.; Tvrdonova, M.; Kanický, V.; Vaculovic, T. Variation of major elements and heavy metals occurrence in hybrid aspen (Populus tremuloides Michx. $\times$ P. tremula L.) tree rings in marginal land. iForest Biogeosciences For. 2020, 13, 24-32. [CrossRef]

48. World Health Organization. WHO Guidelines for Assessing Quality of Herbal Medicines with Reference to Contaminants and Residues; World Health Organization: Geneva, Switzerland, 2007; Available online: https://apps.who.int/iris/handle/10665/43510 (accessed on 20 May 2021).

49. Hoover, J.; Gonzales, M.; Shuey, C.; Barney, Y.; Lewis, J. Elevated Arsenic and Uranium Concentrations in Unregulated Water Sources on the Navajo Nation, USA. Expo. Health 2017, 9, 113-124. [CrossRef]

50. Kumar, A.; Kumar, A.; Cabral-Pinto, M.M.S.; Chaturvedi, A.K.; Shabnam, A.A.; Subrahmanyam, G.; Mondal, R.; Gupta, D.K.; Malyan, S.K.; Dipar, K.S.; et al. Lead Toxicity: Health Hazards, Influence on Food Chain, and Sustainable Remediation Approaches. Int. J. Environ. Res. Public Health 2020, 17, 2179. [CrossRef] [PubMed]

51. Chunhabundit, R. Cadmium Exposure and Potential Health Risk from Foods in Contaminated Area, Thailand. Toxicol. Res. 2016, 32, 65-72. [CrossRef] [PubMed]

52. Satarug, S.; Vesey, D.A.; Gobe, G.C. Health Risk Assessment of Dietary Cadmium Intake: Do Current Guidelines Indicate How Much is Safe? Environ. Health Perspect. 2017, 125, 284-288. [CrossRef] [PubMed]

53. Leyssens, L.; Vinck, B.; Straeten, C.; Wuyts, F.; Maes, L. Cobalt toxicity in humans. A review of the potential sources and systemic health effects. Toxicology 2017, 387. [CrossRef]

54. Stubblefield, W.A.; Van Genderen, E.; Cardwell, A.S.; Heijerick, D.G.; Janssen, C.R.; De Schamphelaere, K.A.C. Acute and Chronic Toxicity of Cobalt to Freshwater Organisms: Using a Species Sensitivity Distribution Approach to Establish International Water Quality Standards. Environ. Toxicol. Chem. 2020, 39, 799-811. [CrossRef]

55. Genchi, G.; Carocci, A.; Lauria, G.; Sinicropi, M.S.; Catalano, A. Nickel: Human Health and Environmental Toxicology. Int. J. Environ. Res. Public Health 2020, 17, 679. [CrossRef]

56. Pohl, P.; Dzimitrowicz, A.; Jedryczko, D.; Szymczycha-Madeja, A.; Welna, M.; Jamroz, P. The determination of elements in herbal teas and medicinal plant formulations and their tisanes. J. Pharm. Biomed. Anal. 2016, 130, 326-335. [CrossRef]

57. Available online: https:/ / eur-lex.europa.eu/eli/dir/2020/2184/oj (accessed on 17 April 2021).

58. Tietz, T.; Lenzner, A.; Kolbaum, A.E.; Zellmer, S.; Riebeling, C.; Gürtler, R.; Jung, C.; Kappenstein, O.; Tentschert, J.; Giulbudagian, M.; et al. Aggregated aluminium exposure: Risk assessment for the general population. Arch. Toxicol. 2019, 93, 3503-3521. [CrossRef]

59. Cuciureanu, R.; Urzică, A.; Voitcu, M.; Antoniu, A. Estimarea aportului zilnic de aluminiu prin consum de alimente [Assessment of daily aluminum intake by food consumption]. Rev. Med. Chir. Soc. Med. Nat. Iasi. 2000, 104, 107-112.

60. Haidu, D.; Párkányi, D.; Moldovan, R.I.; Savii, C.; Pinzaru, I.; Dehelean, C.; Kurunczi, L. Elemental Characterization of Romanian Crop Medicinal Plants by Neutron Activation Analysis. J. Anal. Methods Chem. 2017, 2017, 9748413. [CrossRef] [PubMed]

61. Nirola, R.; Biswas, B.; Megharaj, M.; Subramanian, A.; Thavamani, P.; Aryal, R.; Saint, C. Assessment of chromium hyperaccumulative behaviour using biochemical analytical techniques of greenhouse cultivated Sonchus asper on tannery waste dump site soils. Environ. Sci. Pollut. Res. Int. 2018, 25, 26992-26999. [CrossRef]

62. Artwell, K.; France, N.; Florence, K. Investigation of Some Metals in Leaves and Leaf Extracts of Lippia javanica: Its Daily Intake. J. Environ. Public Health 2017, 2017, 1476328. [CrossRef] [PubMed]

63. Ancuceanu, R.; Dinu, M.; Hovaneţ, M.V.; Anghel, A.I.; Popescu, C.V.; Negreş, S. A Survey of Plant Iron Content-A Semi-Systematic Review. Nutrients 2015, 7, 10320-10351. [CrossRef] [PubMed]

64. Guerra, F.; Gainza, F.; Perez, M.; Zamudio, F. Phytoremediation of heavy metals using poplars (Populus spp.): A glimpse of the plant responses to copper, cadmium and zinc stress. In Handbook of Phytoremediation; Golubev, I.A., Ed.; Nova Science: New York, NY, USA, 2011; pp. 387-413. 
65. Rohanizadegan, M. Analysis of circulating tumor DNA in breast cancer as a diagnostic and prognostic biomarker. Cancer Genet. 2018, 228-229, 159-168. [CrossRef]

66. Wadowska, K.; Bil-Lula, I.; Trembecki, Ł.; Śliwińska-Mossoń, M. Genetic Markers in Lung Cancer Diagnosis: A Review. Int. J. Mol. Sci. 2020, 21, 4569. [CrossRef]

67. Jahanban-Esfahlan, A.; Modaeinama, S.; Abasi, M.; Abbasi, M.M.; Jahanban-Esfahlan, R. Anti Proliferative Properties of Melissa officinalis in Different Human Cancer Cells. Asian Pac. J. Cancer Prev. 2015, 16, 5703-5707. [CrossRef] [PubMed]

68. Miladi, H.; Slama, R.; Mili, D.; Zouari, S.; Bakhrouf, A.; Ammar, E. Essential oil of Thymus vulgaris L. and Rosmarinus officinalis L.: Gas chromatography-mass spectrometry analysis, cytotoxicity and antioxidant properties and antibacterial activities against foodborne pathogens. Nat. Sci. 2013, 5, 729-739. [CrossRef]

69. Mohammad-Hossein, D.; Kazem, A.; Mahdi, F.R. The effect of ethanolic extract of Thymus kotschyanus on cancer cell growth in vitro and depression-like behavior in the mouse. J. Tradit. Complem. Med. 2018, 8, 89-94. [CrossRef]

70. Md, S.; Alhakamy, N.A.; Aldawsari, H.M.; Husain, M.; Kotta, S.; Abdullah, S.T.; A Fahmy, U.; Alfaleh, M.A.; Asfour, H.Z. Formulation Design, Statistical Optimization, and In Vitro Evaluation of a Naringenin Nanoemulsion to Enhance Apoptotic Activity in A549 Lung Cancer Cells. Pharmaceuticals 2020, 13, 152. [CrossRef]

71. Poofery, J.; Khaw-on, P.; Subhawa, S.; Sripanidkulchai, B.; Tantraworasin, A.; Saeteng, S.; Siwachat, S.; Lertprasertsuke, N.; Banjerdpongchai, R. Potential of Thai Herbal Extracts on Lung Cancer Treatment by Inducing Apoptosis and Synergizing Chemotherapy. Molecules 2020, 25, 231. [CrossRef] [PubMed]

72. Wihadmadyatami, H.; Karnati, S.; Hening, P.; Tjahjono, Y.; Maharjanti, F.; Kusindarta, D.L.; Triyono, T. Ethanolic extract Ocimum sanctum Linn. induces an apoptosis in human lung adenocarcinoma (A549) cells. Heliyon 2019, 5, e02772. [CrossRef] [PubMed]

73. Tsai, Y.; Xia, C.; Sun, Z. The Inhibitory Effect of 6-Gingerol on Ubiquitin-Specific Peptidase 14 Enhances Autophagy-Dependent Ferroptosis and Anti-Tumor in vivo and in vitro. Front Pharmacol. 2020, 11, 598555. [CrossRef]

74. Khan, I.; Bahuguna, A.; Bhardwaj, M.; Pal Khaket, T.; Kang, S.C. Carvacrol nanoemulsion evokes cell cycle arrest, apoptosis induction and autophagy inhibition in doxorubicin resistant-A549 cell line. Artif. Cells Nanomed. Biotechnol. 2018, 46, 664-675. [CrossRef]

75. Yang, J.; Chen, H.; Wang, Q.; Deng, S.; Huang, M.; Ma, X.; Song, P.; Du, J.; Huang, Y.; Wen, Y. Inhibitory Effect of Kurarinone on Growth of Human Non-small Cell Lung Cancer: An Experimental Study Both in Vitro and in Vivo Studies. Front. Pharmacol. 2018, 9, 252. [CrossRef] [PubMed]

76. Gezici, S.; Sekeroglu, N.; Kijjoa, A. In vitro Anticancer Activity and Antioxidant Properties of Essential Oils from Populus alba L. and Rosmarinus officinalis L. from South Eastern Anatolia of Turkey. Indian J. Pharm. Educ. Res. 2017, 51, s498-s503. [CrossRef]

77. Pereira, F.G.; Marquete, R.; Leite, K.O.; Cabral, O.V.; May, B.; Mansur, E.; Moreira, D.L. Anatomical aspects, chemical analysis and cytotoxic effect of the essential oil from leaves of Casearia arborea (Salicaceae). Lat. Am. Caribb. Bull. Med. Aromat. Plants 2017, 16, 99-109.

78. Li, J.; Liu, H.; Liu, X.; Hao, S.; Zhang, Z.; Xuan, H. Chinese Poplar Propolis Inhibits MDA-MB-231 Cell Proliferation in an Inflammatory Microenvironment by Targeting Enzymes of the Glycolytic Pathway. J. Immunol. Res. 2021, 2021, 6641341. [CrossRef] [PubMed]

79. Smith, M.S.; Wunder, B.M.; Norris, D.A.; Shellman, Y.G. A Simple Protocol for Using a LDH-Based Cytotoxicity Assay to Assess the Effects of Death and Growth Inhibition at the Same Time. PLoS ONE 2011, 6, e26908. [CrossRef] [PubMed] 